\title{
Mineral Resources in Afghanistan
}

Submitted to the

Office of the A.I.D. Representative

for Afghan Affairs

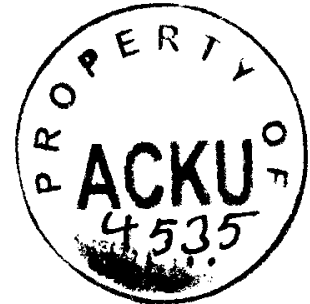

Under

Contract No. 306-0205-C-00-9385-00

Delivery Order No. 15

February 1992

Submitted by

Nathan Associates Inc. and

Louis Berger International, Inc.

A Joint Venture 


\section{CONTENTS}

1. INTRODUCTION AND EXECUTIVE SUMMARY 1

Introduction

Executive Summary

Afghanistan and Its Minerals 2

Development Strategies for Afghanistan's Minerals Sector 3

O/AID/Rep Activities 6

2. A BRIEF HISTORY OF AFGHANISTAN'S MINERALS SECTOR Introduction 9

Exploration and Exploitation History 9

British Geological Investigations in Afghanistan 10

French Geological Investigations in Afghanistan $\quad 10$

German Geological Investigations in Afghanistan 11

Soviet and East Bloc Activities in Afghanistan 11

United States Geological Investigations in Afghanistan 13

Minerals Sector Policies and National Planning 15

Background of National Planning 15

Principal National Plans 16

Treatment of the Minerals Sector in Planning Documents 16

Kabul Government U.N. Conference Presentation 19

$\begin{array}{ll}\text { Two Assessments } & 20\end{array}$

3. FUTURE MINERALS DEVELOPMENT STRATEGIES 25

Introduction $\quad 25$

National Strategy 27

Development of Gas and Petroleum Resources for 28

$\begin{array}{ll}\text { Domestic Consumption } & 28 \\ & 29\end{array}$

Electric Power Supply 31

\begin{tabular}{ll} 
Energy for Cooking and Heating & 31 \\
Energy for Agriculture & 32 \\
\hline
\end{tabular}

Exploiting Other Mineral Resources

Mineral Law and Rights .

Training and Exploration $\quad 34$

Conclusion 36

Regional Strategy $\quad 37$

Natural Gas Sales to the USSR 37

Fertilizer Production 38

Electricity Production 38

Conclusion 40

International Strategy 40

Organization of Ministry of Mining and Petroleum 43

Legal framework 43

Transportation Studies $\quad 44$

Integration of Railway and Mining Development 45

Training $\quad 48$

Exploration $\quad 48$

$\begin{array}{lr}\text { Conclusions } & 48\end{array}$ 


\section{CONTENTS}

(continued)

4. AFGHANISTAN'S MINERAL RESOURCES: LOCATIONS,

POTENTIALS, AND INFORMATION SOURCES

Introduction

Identity and Location of Afghanistan's Mineral Resources

Potential Smelting Operations

Ainak Copper

Hajigak Iron

Hydrocarbon Resources

Petroleum

Natural Gas

Coal

Hydroelectric Power

Recent Maps, Inventories, and Studies of

Afghanistan's Mineral Resources

Pertinent Publications, 1972-1973

Pertinent Publications, 1974-1977

Recent Publications

Gaining Access to Information from Soviet Bloc Sources

Background

Approach to Obtaining Information

Conclusions

Other Sources

REFERENCES

Appendix. ANNOTATED BIBLIOGRAPHY

\section{FIGURES}

Figure 1. Mineral Resources Overview

Figure 2. Metallic Minerals and Metallogenetic Zones

Figure 3. Hydrocarbons

Figure 4. Mineral Resources of Afghanistan

\section{TABLE}

Table 1. Known Metal, Mineral, and Hydrocarbon Occurrences in Afghanistan of Potential Commercial Significance

\section{EXHIBIT}

Exhibit 1. Railway Ownership 


\section{GLOSSARY}

aragonite

barite

barium

beneficiate

cadmium

calcite

carbonatite

celestite

cesium

chromite

CIS
Mineral similar to calcite (see calcite) but with differences in crystallization and a higher specific gravity. The crystals are transparent to translucent, have a glassy luster, and are usually white or colorless.

The most common barium-bearing mineral. Principal raw material for barium hydroxide used in refining sugar. Also used as a pigment for paint, as a filler in paper and cloth, and in preparing heavy drilling sludge in the petroleum industry. See barium.

Highly reactive chemical element. Used as a "getter" to remove gases from vacuum tubes and for clinical testing.

To concentrate or otherwise prepare ore for smelting.

White ductile mineral resembling tin in appearance, used in plating and making certain alloys.

Calcium carbonate, a major constituent of limestone, marble, and chalk. Calcite is extremely important as a commercial mineral; it is used as a building stone and in the manufacture of plaster, cement, and glass.

Carbonite-rich rocks of magmatic derivation. Can be sources of niobium, phosphate, barite, thorium, vermiculite, magnetite, titanium, and carbonate rock.

The principal ore of strontium. See strontium.

Rare, highly reactive, soft metallic element used in photoelectric cells and pickup tubes of television cameras. Small amounts of cesium are used to remove traces of air from vacuum tubes. It may also be used to provide thrust for rockets and for electric motor armatures.

Principal ore of chromium. Used in manufacture of refractories and as a source of alloys of iron and chromium.

Confederation of Independent States, consisting of 12 countries that were formerly republics of the USSR:

Armenia, Azerbaijan, Belarus (formerly Byelorussia), Georgia, Kazakhstan, Kyrgyzstan (formerly Kirghizia), Moldova (formerly Moldavia), Russia, Tajikistan (formerly Tadzhikistan), Turkmenistan (formerly Turkmenia), Ukraine, and Uzbekistan. 
DAP

dolomite

fluorite

GEOKART

GIS

kunzite

$\mathrm{kW}$

lapis lazuli

lithium

magnetite

molybdenum

MT

muscovite diammonium phosphate fertilizer

Mineral composed of calcium and magnesium carbonate, used by iron and steel manufacturers in the smelting process. When finely ground, used as a filler in paint, putty, and rubber. Marble composed of dolomite crystals is famous for its unusual colors and is used as a building material.

Calcium fluorite, the principal source of fluorine. Also used as a flux in metallurgy and as an ornament. Fluorite is also called fluorspar.

Organization for Surveying and Cartography, Warsaw, Poland.

Geographic Information System

Transparent pinkish-lilac variety of spodumene, used as a gem.

kilowatt

Deep blue mineral composed mainly of lazurite with smaller quantities of other minerals, used chiefly as a gem or pigment.

Extracted lithium is used in air conditioning, metal alloys, lubricating greases, ceramics, welding, and brazing. Other applications include fusion weapons, nuclear power, and high energy fuels. See spodumene.

Important iron ore that is strongly attracted by a magnet.

Silver-white high-melting metal element. One of the strongest and most widely used of refractory metals, molybdenum conducts heat and electricity easily. It is mixed with iron and steel to produce strong alloys, particularly for hard, high-speed cutting tools. Used for aircraft and missile parts. Molybdenum compounds have many industrial uses.

metric tons

Light-colored mica. Sheets and ground material are used in the electrical and electronics industry, paper and paint manufacturing; as a lubricant, dusting powder, and filler; and for special decoration effects. 
MW

niobium

pegmatite

phosphorite

pyrolusite

rubidium

serpentine

skarn

SOFRERAIL

spodumene

strontium

tantalum

tectonics megawatt

Formerly called columbium. Soft metallic element found in nature with tantalum, which it closely resembles. Used in stainless and other alloys and the cores of reactors and in the manufacture of superconducting magnets.

Coarsely crystalline granite or other high-silica rock occurring in veins or dikes. A complex silicate, of ten black, but having various colored transparent varieties used as gems. See spodumene.

Form of the mineral apatite, the principal source of phosphate for fertilizer.

The principal ore of manganese.

Silver-white metallic, active element resembling potassium, used in electric cells and radio vacuum tubes.

Hydrous magnesium silicate, a green-sometimes spottedmineral used for architectural and decorative purposes.

Contact metamorphic rock, rich in iron.

French company that carried out studies of a railroad in Afghanistan and of a road to connect Hajigak iron deposits to a projected rail link.

Lithium aluminum silicate, a mineral occurring in prismatic crystals, often used as gems. Important ore as a source of lithium and of ceramic materials. Gems include hiddenite (green), kunzite (lilac), and yellow and yellow-green gems. See lithium.

Various strontium salts are used in sugar-beet refining and in the manufacture of fireworks, fuses, and other pyrotechnic products.

Gray, hard, rare mineral (usually associated with niobium) used because of its resistance to corrosion by most acids, for chemical, dental, and surgical instruments.

Branch of geology concerned with structure, particularly folding and faulting. 
thorium

tourmaline

wolfram

UNDP

USGS

USSR

vermiculite
Grayish-white, lustrous, somewhat ductile and malleable radioactive element. Used as a source of nuclear energy, in sun lamp and vacuum tube filament coatings, and in alloys.

Complex silicate of aluminum and boron with varying amounts of other minerals. The principal gem varieties are pink to red, blue, and green.

tungsten

United Nations Development Programme

United States Geological Survey

Union of Soviet Socialist Republics

Clay mineral resembling mica. Expanded by heat and used for insulation, soundproofing, and other forms of shielding. 


\section{PREFACE}

This report was prepared in response to Delivery Order No. 15 of A.I.D. Contract No. 306-0205-C-00-9385-00, Afghanistan Studies Project. The work was carried out by the Joint Venture of Nathan Associates Inc. and Louis Berger International, Inc.

Principal contributors to the work were Dr. John F. Shroder, Mr. Forrest Cookson, Dr. Paul Belasky, Mr. Yaqub Roshan, Mr. Robert Watrel, and Ms. Melissa Wells. The work was carried out under the supervision of Robert R. Nathan and Harvey A. Lerner. All research activities were carried out in the United States. No visits to Pakistan or field surveys in Afghanistan were conducted. 


\title{
Chapter 1
}

\section{INTRODUCTION AND EXECUTIVE SUMMARY}

\author{
Introduction
}

This report was prepared in response to Delivery Order No. 15 under A.I.D. Contract No. 306-0205-C-00-9385-00, Afghanistan Studies Project. The objectives of the Delivery Order are to

1. Provide an objective, single-volume, resource document, with maps, for development officials interested in mineral and energy development potentials in Afghanistan.

2. Summarize the results of past studies and informed experience, particularly as they bear on the potential economic feasibility, the realistically attainable production and processing activities, and the potential foreign exchange benefits of undertaking mineral and energy projects following a resolution of the current conflict.

3. Provide geographically defined data on the location of Afghanistan's principal mineral deposits for inclusion in the O/AID/Rep's Geographic Information System.

4. Suggest ways in which A.I.D. could contribute to mineral and energy development projects during the resettlement and reconstruction of Afghanistan.

This report consists of four chapters. Chapter 1 provides an introduction to the report and a summary of its contents. Chapter 2 presents a brief history of Afghanistan's minerals sector. Chapter 3 discusses alternative strategies for the future development of Afghanistan's minerals sector and also identifies six activities that O/AID/Rep or other donors could undertake at this time. Chapter 4 contains information on the location and potential of Afghanistan's mineral resources and identifies information sources. 
The Scope of Work for Delivery Order No. 15 is limited to Afghanistan's mineral resources within the earth and does not include renewable energy resources such as hydroelectric power, forests, and sunlight. Nevertheless, our discussion does give limited treatment to the energy subsector as a whole and considers future possibilities for using hydroelectric and solar power in the context of general strategies for exploiting Afghanistan's energy-related mineral resources.

\section{Executive Summary}

This report is intended to serve as a reference source of the mineral resources of Afghanistan, the possibilities for their exploitation, needs for further exploration, and strategies and policies that Afghanistan might employ to develop its mineral resources with the support of bilateral assistance, regional and worldwide development institutions, and the private sector.

\section{Afghanistan and Its Minerals}

Afghanistan has a wide variety of mineral resources including apatite, agates, amethysts, aquamarines, aragonite, asbestos, barium, bauxite, beryllium, bismuth, boron, cadmium, calcite, celestite, cesium, chromium, clays, coal, copper, dolomite, emeralds, fluorine, gold, garnets, graphite, gypsum, iron, kunzite, lapis lazuli, lead, lignite, lithium, magnesium, marble, mica, manganese, mercury, molybdenum, muscovite, natural gas, nickel, peat, petroleum, phosphorus, quartz, rubidium, rubies, salt, serpentine, shale, silver, spodumene, strontium, sulphur, talc, tantalum, thorium, tin, tourmalines, tungsten, and zinc. Mineral occurrences with possible commercial significance are listed in the table in Chapter 4 of this report.

Despite a lengthy history of small-scale mining of gems, gold, copper, and coal, and some serious early foreign investigative activities, systematic explorations of the country's mineral resources were not undertaken until the 1950s. During that decade and thereafter, Afghanistan's mineral resources became a subject of considerable interest to Western and Eastern bloc countries as well as the Government of Afghanistan itself.

Afghanistan received considerable foreign assistance in the three decades before the coup in 1978, but the size of its mineral extraction sector remained quite modest. With the exception of exports of natural gas to the Soviet Union, minerals production had little impact on Afghanistan's external trade position. During the invasion of Afghanistan, the Soviets undertook efforts to develop some of the country's mineral deposits for export to the USSR. However, the ongoing hostilities severely hampered both new and ongoing extraction efforts. 
Coal mining, which started on a modest scale in Afghanistan, was modernized and expanded to some degree during the 1950s and 1960s with assistance from Czechoslovakia and the United States. With Soviet assistance, natural gas was found in northern Afghanistan in 1960. Most natural gas production was sent to the Soviet Union by pipeline. Only about a fifth of the natural gas production was used for domestic purposes. The Seven-Year Development Plan issued by the Daoud government in 1976 envisioned extension of the natural gas pipelines southward within Afghanistan for use principally by industrial and mining projects. On the basis of Afghan assessments of domestic crude oil reserves, the Seven-Year Plan also envisioned the construction of a refinery large enough to fill most of the country's requirements for petroleum products. However, neither the Daoud government nor its successors were able to obtain financing for such a project. Instead the Soviets encouraged the Afghans to develop coal reserves to fill the fuel requirements of Afghan industry and households. Coal-based briquettes were seen as an alternative to use of fuelwood, which was depleting Afghanistan's forests.

Substantial iron deposits exist at Hajigak in Bamian province. Large copper deposits are located at Ainak in Logar province. Exploitation of Hajigak iron ore was a major component of the 1975 Seven-Year Development Plan. A 1978 World Bank report suggested that development of Ainak copper deposits might constitute a better use of Afghanistan's constrained resources. A large project for utilizing Ainak copper was undertaken with Soviet and Czech assistance during the Soviet occupation, but Resistance efforts effectively limited production at the mine.

\section{Development Strategies for}

Afghanistan's Minerals Sector

There are three main strategic approaches to the development of Afghanistan's minerals sector:

A "national" or "inward-oriented" strategy that aims to rehabilitate and extend the present mineral exploitation system principally in order to serve domestic needs within Afghanistan. Such a strategy would continue traditional exports of gemstones and, to the extent feasible and advisable, exports of natural gas to the Soviet Union. Such a strategy would require relatively modest investment and financial assistance.

- A "regionar" strategy that, in addition to serving Afghanistan's internal needs for minerals and mineral products, aims to serve markets in countries close to Afghanistan. Such a strategy would require significant investment, active collaboration with one or more neighboring countries, and considerable assistance from worldwide, regional, and national development institutions. 
An "international" strategy that seeks to serve world markets including purchasers located at points remote from Central and South Asia. Such a strategy would involve close collaboration with multinational corporations and substantial assistance from leading development finance institutions. This strategy would require the construction of a railway to carry Afghanistan's mineral ores and products together with suitable improvements at the ports from which these commodities are exported.

Whichever one or combination of these strategies is pursued, it should be accompanied by realistic plans for exploration, training, and meeting domestic energy needs.

- Training. Programs are needed to provide Afghans with the manpower skills to develop the country's minerals sector. Training should be provided for geologists, geochemists, mining engineers, petroleum engineers, and legal specialists, all of whom are needed to support each of the development strategies. Effective university training programs must be established and linked to graduate programs in Europe and the United States. The organization of these programs should take a long view, with early emphasis on building up the teaching faculties.

- Exploration: The exploration work that has been done to date must be continued and expanded. A technical assistance program should mobilize knowledgeable geologists on a worldwide basis. To the extent feasible, geologists who have acquired knowledge in the last decade should be encouraged to share their knowledge and data with Afghan professionals engaged in exploration and assessment of Afghanistan's mineral resources.

Domestic Energy Development: Whatever the strategy followed for mineral resource development, it is essential that the economy provide much more energy for domestic uses, including

- Increased generation and wider geographic distribution of electricity,

- Heating and production in industrial establishments,

- Heating and cooking for households, and

- Transportation.

The national strategy for mineral development focuses on exploitation of mineral resources primarily to meet the needs of domestic markets. The principal concern of this strategy is developing sources of domestic energy supply and raw materials for fertilizer production. Traditional export markets 


\section{Chapter 2}

\section{A BRIEF HISTORY OF AFGHANISTAN'S MINERALS SECTOR}

\section{Introduction}

This chapter provides a brief history of minerals exploration, exploitation, and planning in Afghanistan. The chapter first describes the early history of the minerals sector and the roles of Great Britain, France, Germany, the Soviet bloc, and the United States in Afghanistan's minerals development activities. ${ }^{1}$ It then deals with the policy background and the treatment of the minerals sector in five national plans spanning the years from 1962 to 1983. The treatment of the minerals sector in the Kabul government's Country Presentation to the Second United Nations Conference on the Least Developed Countries (1990) also is briefly reviewed. The chapter closes with summaries of two assessments of the planning for the minerals sector in Afghanistan, written more than a decade apart. The first is in the World Bank report, Afghanistan:The Journey to Economic Development (1978). The second is in a U.S. Department of Energy study, Afghanistan's Energy and Natural Resources (1989).

\section{Exploration and Exploitation History}

In ancient days, when Afghanistan occupied an important position on the overland trading route between China and Europe, the minerals of the eastern Hindu Kush-rubies, gold, lapis lazuli, and salt-attracted merchants from great distances. However, apart from traditional production of these minerals, the country's mineral resources were left unexplored and unexploited for most of its history.

The Government of Afghanistan attempted to survey the country's mineral resources before World War II. The Directorate of Mines was expanded into the Ministry of Mines, and attempts were made to exploit

\footnotetext{
${ }^{1}$ More recent minerals development is discussed in Chapter 4 of this report.
} 
The national strategy would focus on meeting some resettlement needs and prepare the way for more ambitious general development. The regional strategy, while seemingly less risky than the international strategy, is in fact hazardous due to the uncertain attitudes of Afghanistan's neighbors and the tenuous circumstances of their economies.

\section{O/AID/Rep Activities}

The Mission should consider undertaking six principal activities at this time:

Facilitate the development of minihydroelectric plants.

Work on selection and design could begin at once and implementation might be achieved even before there is a final political settlement.

- Initiate work facility rehabilitation studies.

Rehabilitation studies would draw together all information on the current status of natural gas, fertilizer production, electric power, and other pertinent facilities and identify those most in need of repair.

- Initiate revision of mining and petroleum codes.

Respected Afghan engineers and attorneys could be assembled to work with foreign experts to draw up codes for consideration by a new government.

- Prepare and initiate a training program.

Preparation of a training program to meet mineral sector needs could well fit into new O/AID/Rep Human Resource Development initiatives.

- Prepare a mineral and petroleum exploration program.

A collaborative effort among Afghan professionals and foreign technical experts should define a program of mineral exploration in Afghanistan, project costs of alternative levels of effort, and explore sources of funding.

- Present seminars on mineral development to Afghan political and military leaders. 
Seminars for Afghan leaders in areas where mineral development projects are likely to be located should emphasize legal, technical, financial, and other essential requirements for effective mineral resource development.

If projects, studies, and activities along these lines are undertaken in the near future, some of the preparatory work needed by the new government could be completed in advance and valuable time could be gained. In essence, what A.I.D. can do most effectively at this stage in the development of Afghanistan's mineral and hydrocarbon sector is to support the creation of the building blocks of a program. Once such building blocks are in place and a settlement is achieved, mineral sector development can move forward promptly with assistance from a variety of donors and international development agencies. 


\section{Chapter 2}

\section{A BRIEF HISTORY OF AFGHANISTAN'S MINERALS SECTOR}

\section{Introduction}

This chapter provides a brief history of minerals exploration, exploitation, and planning in Afghanistan. The chapter first describes the early history of the minerals sector and the roles of Great Britain, France, Germany, the Soviet bloc, and the United States in Afghanistan's minerals development activities.' It then deals with the policy background and the treatment of the minerals sector in five national plans spanning the years from 1962 to 1983. The treatment of the minerals sector in the Kabul government's Country Presentation to the Second United Nations Conference on the Least Developed Countries (1990) also is briefly reviewed. The chapter closes with summaries of two assessments of the planning for the minerals sector in Afghanistan, written more than a decade apart. The first is in the World Bank report, Afghanistan: The Journey to Economic Development (1978). The second is in a U.S. Department of Energy study, Afghanistan's Energy and Natural Resources (1989).

\section{Exploration and Exploitation History}

In ancient days, when Afghanistan occupied an important position on the overland trading route between China and Europe, the minerals of the eastern Hindu Kush-rubies, gold, lapis lazuli, and salt-attracted merchants from great distances. However, apart from traditional production of these minerals, the country's mineral resources were left unexplored and unexploited for most of its history.

The Government of Afghanistan attempted to survey the country's mineral resources before World War II. The Directorate of Mines was expanded into the Ministry of Mines, and attempts were made to exploit

\footnotetext{
${ }^{1}$ More recent minerals development is discussed in Chapter 4 of this report.
} 
Afghanistan's gold and coal deposits. However, only 70 pounds of gold were mined between 1939 and 1943, and the project was abandoned in 1948. The mining of coal, though expensive, continued because of the country's great need for this resource. The only profitable mining operation was lapis lazuli, which a government monopoly exported to Germany until the outbreak of World War II.

For the most part, the history of minerals exploration and exploitation, in the modern sense of these terms, has been a history of involvement by foreign governments, firms, and experts. The subsections that follow trace some of the principal developments.

\section{British Geological Investigations in Afghanistan}

The British initiated the first resource analysis in Afghanistan more than 170 years ago in a series of military incursions in which the expeditions were accompanied by people versed in resource exploration techniques. In general, the rationale for the geological exploration was to locate resources that could be used in trade for British industrial products. However, topographical mapping was primarily for military purposes. The Afghan Amir Abdur al-Rahman Khan paid the British geologist Griesbach to discover exploitable minerals, but later complained that the geologist seemed more interested in Afghan politics and topographic mapping than in his principal task. When presented with a plan for resource exploitation, however, the Amir did not act.

Afghanistan was considered part of the British sphere of influence until after World War I, and other countries were precluded from exploring. British geological exploration continued intermittently until shortly after World War II. It was resumed on only an occasional consulting basis in the 1970s under the auspices of the United Nations, with the investigations of mineral resource expert Richard H. Sillitoe and others.

\section{French Geological Investigations in Afghanistan}

French geologists expressed an interest in Afghanistan soon after the British allowed the country to handle its own foreign affairs in 1919. Raymond Furon published his studies on the mineral resources of Afghanistan in 1924. In 1947, Akram published in Paris an analytical bibliography of Afghanistan that included mineral resource material. The Government of France established a French Cultural Mission and school in Kabul after World War II. Several French geologists worked intensively in the country, particularly in the 1960s and 1970s. De Lapparent and his group were responsible for mapping many areas in the south and central parts of the country, but they also explored Badakhshan and other northern areas. In general, the French confined their work to basic geological mapping of small regions. They also studied the Hajigak iron deposit in the central Koh-i-Baba 
Range, as well as the Sar-i-Sang lapis lazuli and other deposits. Perhaps most significantly, however, in 1950 the Afghans sought technical help from the French to develop possible petroleum resources in the northwest. Soviet objections led to the ejection of French petroleum geologists from the northern areas in 1954. Later, in 1975, an oil exploration agreement for the south of Afghanistan was signed by the French company Cie. Française des Petroles (TOTAL), but drilling was terminated in 1977. Otherwise, French tectonicists ${ }^{2}$ are especially well known for their work in fitting Afghanistan and South Asia into the general scheme of plate tectonics, but this is not particularly a part of mineral exploration.

\section{German Geological Investigations in Afghanistan}

As in the case of the French, various German explorers came to Afghanistan after World War I. However, German geological work did not begin in earnest until after World War II. In 1968, for example, Kaever published a bibliography of literature on Afghanistan geology and paleontology for the years 1945-1967. The German Geological Mission in Afghanistan became responsible for training, in German, Afghan geologists in the Department of Geology in the College of Sciences at Kabul University. This program conspicuously paralleled a similar program in Russian to train geologists at the USSR-dominated Polytechnic. The German geologists also were responsible for mapping central and southwestern Afghanistan. Little work was done specifically on mineral resources, but in 1972 Schreiber, Weippert, Wittekindt, and Wolfart did publish in English an important article on "Geology and Petroleum Potentials of Central and South Afghanistan" in the American Association of Petroleum Geologists Bulletin. In 1980, Wolfart and Wittekindt published in German a book on the Geology of Afghanistan in which a 25-page chapter on "Raw Material Occurrences" summarized the same information as a 1977 Government of Afghanistan report.

\section{Soviet and East Bloc Activities in Afghanistan}

Immediately after Afghanistan regained from the British the right to conduct its own foreign affairs, a Russian delegation arrived in Kabul. In 1927, Obruchev, one of the most famous of all Russian geologists, published a book on the "Fossil Riches of Afghanistan." Soviet pressure on the Government of Afghanistan to explore and develop its mineral resources did not begin in earnest until the 1950s and 1960s when the unwillingness of the United States government to respond to Afghanistan's military needs led to increasing Soviet involvement in the country.

\footnotetext{
${ }^{2}$ Tectonics is a branch of geology concerned with structural features as a whole, particularly with the folding and faulting in the earth's crust.
} 
After the French and a later Swedish exploration group were removed in the face of Soviet pressure, Eastern bloc drilling for oil and gas began in 1956. The first success was registered in 1958 by Czech and Russian technicians.

By mid-1963, development of a domestic natural-gas producing industry had begun. Some oil was discovered. In 1967, a 97.5-km gas pipeline $820 \mathrm{~mm}$ in diameter was completed between the Shiberghan fields in the northwest, under the Amu Darya River, to the other side of the river in Kelift, USSR. In that year, 20.7 million $\mathrm{m}^{3}$ of gas was exported and the following year exports reached 1.5 billion $\mathrm{m}^{3}$. Construction began on a chemical fertilizer plant and a thermal power plant at Mazar-e-Sharif using natural gas.

Throughout the decade of the 1970s the Soviet Technoexport group of geoscientists in Afghanistan devoted a great deal of time and effort to geological exploration. As the exploration proceeded, Soviet control over resources was achieved by political maneuver, as in the case of oil and gas exploration in both northern and southern regions of the country. The northern oil wells were capped to await future developments, but the gas was exported by pipeline to the USSR. In 1974, the gas pipeline beneath the Amu Darya was rebuilt as an aerial line. Production by that time was up to 2.5 billion $\mathrm{m}^{3}$ with 80 percent going to the USSR. The right to exploit the rich Ainak copper deposit was also assigned to the Soviet Union on the same basis. Exact details are uncertain, but the Deputy Foreign Minister in the Daoud government, Waheed Abdullah, indicated at the University of Nebraska at Omaha in 1976 that Soviet threats concerning economic and military assistance debts caused Daoud to assign the deposit to the USSR over other higher bids.

Following the Marxist coup in 1978 and the Soviet invasion in 1979, Soviet aid to Afghanistan increased dramatically. The northern oil and gas area near Shiberghan was designated the principal base for industrial expansion. A number of resource exploitation contracts, negotiated by the earlier Daoud regime with the USSR, were implemented. These included (1) $\$ 30$ million for petroleum equipment, (2) studies and designs for the $\$ 600$ million Ainak copper smelter and another natural gas fertilizer plant near Mazar-e-Sharif, (3) \$22 million for detailed mapping of northern Afghanistan, (4) $\$ 50$ million for the first rail and vehicle bridge over the Amu Darya River, and (5) $\$ 5$ million for the renovation of the Sher Khan port there. New oil discoveries in the north also led to plans for construction of a new 500,000ton. oil refinery.

In May 1979, a new group of 200 Soviet geologists arrived in the north of Afghanistan to look for gas, and a short time later they announced discovery of another gas-bearing zone capable of producing 2.5 billion $\mathrm{m}^{3}$ a year. Work on three oil fields and the refinery also began at that time. In addition, in early 1980, more Soviet experts were reported to be in Afghanistan to increase gas production by 65 percent. It is thought that the 
gas exports were to service the debt load, including some of the costs of the Soviet military occupation. Afghanistan's gas exports to the Soviet Union were priced artificially lower than world rates. Many wells were reported to have been capped and sealed when Soviet troops departed from Afghanistan in 1989.

The Soviet bloc was also involved in coal exploitation. The Bulgarian government promised Afghanistan six complete coal briquette manufacturing units. The Czechs had first laid out the coal mines in 1954. A new group of Czechs arrived in 1978 and succeeded in tripling production by 1980 . The Czechs were also involved in setting up world standard cement manufacturing facilities.

The chief engineer of the Afghan Geological Survey Department reported that the Soviets began uranium mining in the mountains of Khawaja Rawash in 1984. It was also said that the Soviets were mining uranium between Herat and Shidand and in the Khakriz area of Kandahar province. Only Soviet personnel were involved in these operations and all production was sent to the Soviet Union. The Soviets were also believed to be involved in the mining of chromium ore in Nangahar and Logar provinces.

Preparations were made for tapping copper deposits at Ainak with Soviet and Czechoslovak aid. The Afghan ore is believed to be significantly superior to that available in the Soviet Union. A Soviet firm prepared the needed infrastructure for the mine and mill at the project site, while a smelter was being built near the Soviet Embassy in Kabul. Resistance activities are believed to have effectively thwarted the implementation of this project.

\section{United States Geological Investigations in Afghanistan}

In 1919, the Afghan government first turned to the United States to develop strategies for resource exploration, in spite of several diplomatic rebuffs from Washington. Inland Exploration Company of New York, a consortium including Texaco and Seaboard, was granted a 25-year exclusive oil concession, as well as mineral exploration rights leading to exclusivity. Several U.S. geologists (Clapp, Fox, and others) then discovered mineral deposits and potential oil formations, which the Soviets eventually brought into production. The company abruptly abandoned the concessions in 1938 because of concerns with transport costs and the impending outbreak of World War II. The Afghans were shocked by this precipitous move and attributed Inland's withdrawal to devious political motives.

Vital U.S. aid to Afghanistan during World War II helped alleviate these fears, and in 1946 the Morrison-Knudsen Construction Company was employed to begin an ambitious irrigation and land development scheme in the Helmand Valley. In 1949, 11 chromite occurrences in the Logar Valley in northeast 
Afghanistan were investigated for the government's Ministry of Mines. The work was carried out under the supervision of two Americans temporarily assigned from the U.S. Bureau of Mines. A U.S. mining consultant to the Ministry of Mines organized the investigations. Three of the deposits were mapped by an employee of the U.S. Geological Survey. Morrison-Knudsen Afghanistan, Inc. did the drilling under contract (Volin 1950).

A mineral resource development project was one of the earliest sustained activities undertaken by the U.S. government in Afghanistan. Technical assistance personnel worked in Afghanistan on this project from 1951 through 1967. Principal emphasis was on increasing coal production, but Bureau of Mines advisers also carried out surveys and assisted in resolving technical issues relating to the production of beryl, chrome, talc, slate, salt, and other mineral resources (Williams 1957).

In the late 1950s, David Cerkel and Ralph L. Miller of the U.S. Geological Survey were brought to Afghanistan to write a free enterpriseoriented Petroleum Law for Afghanistan. The resulting 49-page booklet, published in Kabul in 1958, dealt with reconnaissance permits, exploration permits, exploitation concessions, royalties, and taxes, and provided for the rights and obligations of holders of petroleum rights (Cerkel and Miller 1957). The procedures were designed to facilitate participation in resource work by foreign companies, a process that proved successful for the countries of the Persian Gulf and elsewhere. The budding petroleum industry was taken over by the Soviets at that time and little real progress on petroleum law was made after that.

In 1961, Morrison Knudsen and its subcontractors prepared a document entitled "Southern Afghanistan Reconnaissance Geological Map," which was included in a proposal to the Royal Government of Afghanistan, Ministry of Plans and Ministry of Mines and Industries for a natural resources inventory and evaluation of Afghanistan. No action was taken on this proposal.

Nevertheless, the increasing interest in Afghanistan's resource potential led to recognition of the need to produce high-quality, large-scale topographic maps that could be used to map geological features and plan development projects. U.S. teams prepared to fly stereoscopic coverage of the entire country but were prevented by the Soviets from photographing the northern third. Overlap between the resulting U.S. and Soviet sets of maps was incompatible, although ground surveys and control points were used carefully. Throughout the 1960 s these maps were rather freely available in Kabul, and complete sets at scales of 1:50,000, 1:100,000, and 1:250,000 were obtained by a number of U.S. groups. A set was also supplied by Fairchild Surveys to various agencies of the U.S. government and became the basis of the Department of Defense (DOD) map catalogue series. A complete DOD set was available in the A.I.D. Library in Kabul in the late 1970s but has since been dispersed. 
In the early 1960s, the U.S. Department of State reportedly took the view that the mineral resources of Afghanistan held little interest for commercial entities in the United States or other Western countries. This attitude has in part been attributed to an internal document produced in about 1963 by A. A. Michel, The Natural Resources of Afghanistan, which found Afghanistan's natural resources to be distinctly limited and expressed negative opinions concerning their commercial potential. Michel made clear, however, that drastic new analyses would be necessary if important deposits were subsequently located.

From 1960 to 1970, A.I.D. financed services for Afghanistan by the U.S. Geological Survey. Assistance focused on coal production and on searches for potassium and other minerals. A.I.D. also financed aerial photographic and mapping activities and assistance to the Afghan Cartographic Institute during the 1960s. In 1968, Charles W. Sweetwood, Minerals and Petroleum Attache, compiled a map at 1:2,000,000 scale of Important Mineral Occurrences in the country.

\section{Minerals Sector Policies and National Planning}

This section traces Afghanistan's minerals sector policies through five national plans prepared before the communist coup and a 1990 presentation by the Kabul government to the Second United Nations Conference on the Least Developed Countries. Of all the planning documents reviewed, the fullest and most extensive treatment of the minerals sector is in the First Seven-Year Economic and Social Development Plan (March 1976-March 1983), issued not long before the Daoud government was overthrown in the 1978 communist coup.

\section{Background of National Planning}

Formal national planning in Afghanistan was first undertaken in the mid-1950s, following a long period in which most economic development relied on the close association of the government with the privately owned Bank Melli. Bank Melli was founded in 1932 by Abdul Majid Zabuli. The bank provided financial backing for the Consolidated Cotton Company, the Textile Company, the Baghlan Sugar Company, and Afghanistan's karakul trade. Industrial concerns operated under the sherkat system, a monopoly concession in which the government could control 40 to 45 percent of the firm's capital without substantial investment. Members of the royal family and high government officials owned blocks of shares, so government cooperation was assured. The country's elite made large profits from the system. Most of these profits were reinvested.

The growth of domestic industry and foreign trade was halted by World War II and grew very slowly thereafter. A turning point came in 1950 
when the U.S. Import-Export Bank declined to underwrite any of the Bank Melli's industrial projects that included the expansion of cotton textile, sugar, and hydroelectric production in the eastern and northern part of the country. A second change came with the appointment of Muhammad Daoud as Prime Minister (1953-1963). Daoud, who was much impressed by the economic progress being achieved in Turkey, India, and Soviet Central Asia through state action, sought a "guided economy." In 1956, Daoud's government issued the First Five-Year Plan. Most of the industrial holdings of the Bank Melli were sold to the government. The government allocated foreign exchange at differential rates in support of investment priorities established by the state. By the start of the second Five-Year Plan in 1962, the economy had the trappings of state control, although private foreign investment was permitted and some observers questioned the seriousness of the government's commitment to planned economic development. Following Daoud's resignation in 1963, there were some attempts to foster private investment in industry, but public sector industry continued to dominate in the Afghan economy. After Daoud returned to power in 1983, etatist policies were greatly reinforced and private investment slowed.

\section{Principal National Plans.}

Afghanistan's economy has been guided by a series of multi-year plans since the mid-1950s. The First Five-Year Plan (1956-1957 to 1960-1961) and the Second Five-Year Plan (1962-1967) emphasized the development of transportation and communications infrastructure. The Third Five-Year Plan (1967-1972) focused more attention on agriculture and irrigation, and on smaller projects. The Fourth Five-Year Plan (1972-1973 to 1976-1977), was not implemented because of the change of government in 1973. In general, the first two Five-Year plans reflected the policies of Prime Minister Daoud. The Third and Fourth Plans reflected some recognition of the limitations of these policies, but investment in state enterprises continued on a substantial scale. The First Seven-Year Economic and Social Development Plan (March 1976March 1983) reflected the renewed commitment of the Daoud Republic to etatist policies and added the key objective of developing heavy industries based on the exploitation of Afghanistan's known iron and copper deposits.

\section{Treatment of the Minerals Sector in Planning Documents}

Whereas the First Plan (1956-1957 to 1960-1961) limited public sector industrial investment exclusively to public defense enterprises and power, the Second Plan (1962-1967) stated:

Experience has shown that private enterprise does not possess adequate resources and experience for undertaking large-scale investment of the type required for achieving a rapid rate of growth. Development of power, gas, petroleum, coal, cement, chemicals, and other basic industries that require large investment funds and also usually involve long gestation periods will be 
the responsibility of the public sector; on the other hand, consumer industry will generally be left to the private sector. (p. 37)

A Survey of Progress, published by the Ministry of Planning in 1959, treated mining as a subset of industry and focused its attention on coal and petroleum. It reported that two coal fields established at Ishpushka and Karkar had recently been mechanized. The main industrial customers were identified as the cement works at Jabel-Seraj, the sugar factory at Baghlan, the flour mill in Kabul, and the textile mill at Gulbarhar. The Survey of Progress also reported that extensive work was being undertaken to locate petroleum resources in the northern provinces of Afghanistan.

The emphasis on natural gas and coal production was retained in the Fourth Five-Year Plan (1972-1973 to 1976-1977). The plan set quantitative and monetary targets for the mining of aragonite, barite, beryl, chromite, and talc. It set an exploratory drilling target of $90,000 \mathrm{~m}$ compared with $65,000 \mathrm{~m}$ for the Third Plan. It reported the preparation of exploratory maps and discovery of deposits of asbestos, copper, gold, lead, mercury, tin, and zinc and also announced a program for oil and gas exploration to be conducted in the south. The Fourth Plan recognized the need for further survey and evaluation work focusing on the volume and economic value of deposits. Although the rhetoric of state control was less pronounced in the Third and Fourth Plans than in the first two, investment in state enterprises engaged in mining grew.

The First Seven-Year Plan (March 1976-March 1983) issued under the Republic of which Mohammad Daoud was both President and Prime Minister set forth a general policy framework, of which the first point underlined the importance of the minerals sector:

The Republican State of Afghanistan attaches great importance to the creation of heavy industries such as mineral extraction, machinery manufacturing units, chemical and power industries, that are basically necessary for rapid economic growth and for the maintenance of an independent economy. Within the public sector, Government will undertake all measures necessary toward this objective. 3 One such measure would be to work on the Hajigak iron

${ }^{3} \mathrm{~A}$. Tawab Assifi, who served as Minister of Mines and Industry under Daoud, nevertheless indicates that policy makers reached a point where they were ready to accept private foreign financial involvement:

By 1975-76, Daoud and others in the Afghan government had at last decided to reduce, not increase, Afghan economic dependency on the Soviet Union and they looked elsewhere for help. Iran agreed to provide credit for railroad construction, a project that would cost nearly a billion dollars.... It was hoped that eventually the remaining funding would come through a 
mines in order to get metal foundries established for industrializing the country. (p. 21)

The emphasis on government action conforms with the provisions of a new Afghan constitution adopted in 1977 that stated that large industries, mines, energy resources, and banks were all public property.

The second point in the general policy framework of the First Seven-Year Plan consigned private investment to small- and medium-sized industries under guidance by the state:

The Republican State will encourage, protect, guide, and control private investments in enterprises in the sphere of small-and medium-level industries as well as handicrafts and in order to ensure harmonious and balanced growth of the national economy will effect coordination and cooperation between the investments in the public and private sectors. (p. 21)

The First Seven-Year Plan recognizes that prior government efforts to develop mines and industries had not fared well:

In the previous Plans, Government invested large sums of money in mining and industrial enterprises. However, most of these enterprises did not operate at full capacity and their management was weak. Due to this the contribution of these enterprises to Government revenue, capital formation, and employment opportunities was not significant:

The volume of output of the mining sector has also been limited so far. Apart from natural gas, lapis lazuli, and coal, there has been no exploitation of other mineral deposits.... (p. 100)

These shortcomings were attributed to a series of constraints including lack of infrastructure, financial resources, geological information, underlying demand, banking facilities, trained professionals, proper balance between the development of the minerals and industrial sectors, and an inventory of projects based on economic and technical studies.

And, once again, the plan announced the need for a program of research and surveys:

consortium of French, German, American, and Japanese companies, and iron billets would be exported to Iran, Pakistan (where the Soviets were building a steel mill), the USSR, and other possible world markets (Assifi 1982-1983). 
Geological research programs and mineral surveys will be conducted more intensively and effectively in order to take maximum advantage of human and financial resources and to provide ground for the development of a program for accelerated exploitation of copper, iron, coal, and other minerals. The main objective is to shorten the gestation period and determine the volume of identified deposits by concentrating surveys in these areas, and at the same time in the context of a long-term plan to design strategies for the utilization of mineral resources and to coordinate activities at all levels.

The plan also discussed specific projects. An iron-smelting project would meet domestic needs and export part of its output and provide the basis for the development of large and small machinery-manufacturing and tool-making industries. The plan envisioned the construction of a copper smelter with an annual capacity of about 100,000 MT. The plan also envisioned a petroleum refinery with a capacity of 200,000 MT of crude oil per year, a new urea fertilizer factory based on natural gas use, a project for extracting sulphur from natural gas supplies, and studies of a program for the liquification of natural gas. A search for a domestic source of phosphates was indicated as a priority with the idea that imports of diammonium phosphate (DAP) fertilizers could eventually be eliminated.

\section{Kabul Government U.N. Conference Presentation}

In 1990, the Kabul government submitted a 28-page "Country Presentation to the Second United Nations Conference on the Least Developed Countries." The substantive sections of the presentation reviewed the performance of the Afghan economy in the 1980s, proposed a program for the 1990s, and described the international support measures the government sought for the forthcoming decade. The sector review showed substantial declines in production of natural gas, coal, and salt between 1978-1979 and 1988-1989. These declines were attributed to inadequate maintenance of equipment, lack of skilled workers, shortages of electricity and diesel fuel, and marketing problems. Delays in exploitation of iron ore, copper, oil, and other resources were attributed to lack of financial resources and securityrelated problems.

In its "Programme for the 1990s," the government states:

In the minerals sector, the immediate priority will be to restore the production levels of natural gas and salt to those of earlier years and to increase the production of coal by fuller utilization of existing mines. With the departure of Soviet experts, gas production has fallen sharply. The help of international institutions and agencies will be requested to restore production levels by efficient utilization of existing gas fields and by tapping new ones....

Apart from the mineral resources that are already being exploited, the Government will develop high-grade iron ore, copper, and other 
deposits that have been recently discovered. Also based on already known reserves, crude oil will be produced with the help of foreign aid. While the crude oil will be for domestic consumption, most of the iron, copper, and other ores in raw and processed form will be intended for export. (pp. 14-15)

The role of government in industry envisioned by the Country Presentation appears to be essentially identical to that articulated in the Second Five-Year Plan and the First Seven-Year Plan, quoted above. The presentation states:

In Afghanistan, public and private industries are complementary. The private sector has comparative advantage in light industries, processing agricultural raw material for exports and import substitution.... Large-scale and heavy industries, for which the private sector does not have the necessary financial and human resources, will remain in the public sector but will be run on sound commercial principles. (pp. 14-15)

\section{Two Assessments}

Two reports, written more than a decade apart, provide interesting and contrasting perspectives on the history of Afghanistan's minerals sector and on plans for the future. The first was issued by the World Bank in 1978, the second by the U.S. Department of Energy in 1989.

\section{Journey to Economic Development (1978)}

In March 1978, 4 months before the communist coup against Daoud's Republic, the World Bank issued Afghanistan:The Journey to Economic Development, a report that took an optimistic view of Afghanistan's prospects for development and articulated a strategy for exploiting potentials for rapid growth that its authors perceived in then-existing conditions. Woven into the fabric of this report are assessments of the heavy industry-minerals sector emphasis in the First Seven-Year Plan and, to a considerably lesser extent, of Afghanistan's prior planning efforts.

The report characterizes the four Five-Year Plans as the work of foreign advisers, including many projects for financing by foreign donors that were prepared without knowledge of conditions in Afghanistan. The First Seven-Year Plan is viewed as sharing many of these characteristics but as a definite step forward.

Journey to Economic Development took issue with the importance the Seven Year-Plan attached to heavy industry and to related transportation investments. The plan allocated 37 percent of investment to industries, mines, 
and energy and 32 percent to transportation and communications, compared with a target of 25 percent of investment assigned to agriculture, animal husbandry, and irrigation. It pointed out that the 32 percent investment for transportation compared with a 15 percent allocation of investment in transportation for the 7 years preceding the plan. This large new allocation reflected the construction of much of a projected railway (23 percent of total investment) from Islam Qala on the Iranian border to Kabul, with a branch line to the Hajigak iron ore deposits. It also pointed out that the second largest project in the plan was a $\$ 120$ million expenditure for the initial stage of a copper smelter to be built and financed by the Soviet Union.

Journey to Economic Development addresses the railway project in the context of the plan's commitment to establish heavy industry within the Afghan economy and to develop the Hajigak iron deposits for this purpose. It ascribes this approach to an outdated Soviet theory that equates development with the creation of heavy industry in general and the steel industry, in particular. The report reviewed preliminary studies that show that exploitation of Hajigak would be feasible only on a massive scale, primarily for export. The construction of a rail link would be necessary, although it could also provide an outlet for other heavy commodities such as copper, coal, and cement. While exhibiting considerable skepticism concerning the economic viability of the railroad itself, the report did not rule out the possibility that particular mineral projects, such as those that would expand coal and cement production, could have the kinds of high economic returns that justify early investment. It noted little progress in setting up the petroleum refinery called for in the Seven-Year Plan and suggested that more urgency in this regard could well be justified. It viewed the energy requirements projected in the plan as unrealistically high because they were based on a premise of rapid development of heavy industry that Journey to Economic Development basically rejected. On the other hand, because Afghanistan imported virtually all of the petroleum that it used and because its natural gas reserves represented a source of export earnings, raw material for fertilizer production, and a domestic energy source of considerable potential, the report regarded hydrocarbon development as a high priority.

Journey to Economic Development proposed quite a different path to rapid development than one based on minerals and heavy industry. The objective was to be the creation of a surplus in livestock and agriculture by extending the use of modern inputs, investing in irrigation systems, improving water management practices, and introducing other technical improvements. Industries that process agricultural output, provide services to agricultural producers, and manufacture consumer goods. (to be purchased out of the widely distributed income derived from increased agricultural production) would then be developed by the private sector which, it argued, would pose no threat to the primacy of state enterprise. The report expressed a concern that the government's preoccupation with state enterprises could lead it into large-scale; capital intensive projects that did not reflect Afghanistan's comparative advantage. 
In the final analysis, however, the World Bank report took the position that Afghanistan's mineral resources offered considerable potential and that further study was needed. A stage had been reached, it argued, in which intensive studies were required as a basis for the selection and phasing of projects.

\section{Afghanistan's Energy and Natural Resources (1989)}

In 1989, 11 years after Journey to Economic Development was written, the U.S. Department of Energy issued a study by Russell Balcome-Rawding and Kathryn Cameron Porter entitled "Afghanistan's Energy and Natural Resources." The study sought to provide a resource perspective for planning reconstruction and economic development efforts. It surveyed opportunities for using natural resources to provide a basis for the future prosperity of the country. Much of the report focused on the unfortunate consequences of Soviet interest and involvement in energy and natural resource development of Afghanistan.

The report ascribed an interest in gaining control of Afghanistan's natural resources as an important Soviet motivation before, during, and after the Soviet invasion of the country. It traced this basic interest back to the 1920 s and argued that controlling Afghan resources was an underlying objective of the USSR's program of assistance to Afghanistan from the 1950s onward. The heavier the Soviet involvement in the minerals sector, the less information (and the more misinformation) on minerals was made available to the Government of Afghanistan and to the world. The report attributed to Soviet influence the omission of a project for linking natural gas fields in the North with Kabul and other major cities by pipeline in the Fourth Five-Year Plan (1972-1973 to 1976-1977). It ascribed the proposals for electric power development included in First Seven-Year Plan (March 1976-March 1983) to Soviet interest in exploiting Ainak copper deposits for itself. It also ascribes delays in petroleum exploration and refinery construction included in the First Seven-Year Plan to the Soviets. It attributed the split between the Daoud government and the Soviet Union (which subsequently led to the communist coup and then to the Soviet invasion) in part to President Daoud's determination to seek help from multilateral organizations for the natural gas pipeline and other minerals-related projects. It summarized reports indicating that the Soviets were directly engaged in uranium and other mining operations during their invasion of Afghanistan and showed that Afghanistan has promising reserves of a number of minerals for which the Soviet Union has present or anticipated quantity and quality deficiencies.

The report argued that energy will be among the first items that must be provided to Afghans as part of a resettlement effort. The already disastrous ecological situation will be further exacerbated with the return of the refugees and will result in further environmental problems as well as diminishing land productivity. The report states that while Afghans will have 
to depend on a variety of fuels as they return, it is crucial to lay the foundation for the development of those energy sources that have not been used of have been underutilized in the past. The report argued for the bottling of natural gas, construction of a natural gas pipeline to the south, giving a high priority to railroad and road construction, and consideration of the installation of a petroleum refinery. It also argued for consideration of the use of photovoltaics and other means of using solar energy, biogas production, and expanded use of electricity.

The report pointed out that foreign assistance to Afghanistan is likely to fall off sharply within a few years of resettlement and that a leading sector will be required to generate enough of a surplus to fill the gap of reduced foreign exchange flowing into the country. It saw the energy and mineral sector as the obvious answer to meet this need. 


\title{
Chapter 3
}

\section{FUTURE MINERALS DEVELOPMENT STRATEGIES}

\author{
Introduction
}

This chapter identifies strategies for developing the mineral and hydrocarbon resources of Afghanistan. As noted in Chapter 1, although renewable energy resources (hydroelectric power, forests, sunlight, and wind) are not strictly within the scope of the present delivery order, some attention is given to these subjects because they account for a portion of the energy sector that includes hydrocarbons (coal, natural gas, and petroleum).

The chapter discusses three strategies that could be followed in the exploitation of Afghanistan's mineral and hydrocarbon resources. "Strategy" refers to the main guidelines for investment in mineral resource exploitation and required ancillary support systems, particularly transportation services. Each strategy is characterized by the geographic scope of the markets it is principally designed to serve and by the scale of exploitation and investment required. The three strategies are

- A "nationar" or "inward-oriented" strategy that aims to rehabilitate and extend the present mineral exploitation system principally designed to serve domestic needs within Afghanistan. Such a strategy would continue traditional exports of gemstones and, to the extent feasible and advisable, exports of natural gas. However, it would not focus on new initiatives aimed at regional or world markets, which would require substantial investment.

- A "regionar" strategy that, in addition to serving Afghanistan's internal needs for minerals and mineral products, aims to serve markets in countries close to Afghanistan. Such a strategy would require significant investment, active collaboration with one or more neighboring countries, and considerable assistance from worldwide, regional, and national development institutions. 
An "international" strategy that seeks to serve world markets including many purchasers at points remote from Central and South Asia. Such a strategy would require collaboration with multinational corporations and substantial assistance from the worldwide, regional, and national development institutions. This strategy would require the construction of a railway to carry Afghanistan's mineral ores and products together with suitable improvements at the port or ports from which these commodities are exported.

The three strategies are not mutually exclusive. The national strategy can easily be combined with either of the others; and some aspects of the regional strategy could be incorporated into the international strategy.

Three elements are common to each of the strategies:

- Implementation of an aggressive exploration program,

- Development of training programs to support the strategy with competent personnel, and

- Provision for the basic energy needs of rural and urban populations.

Even if the ultimate exploitation of mineral resources is deferred for some years, the scientific work on exploration should go forward for several reasons. First, exploration techniques have improved greatly and the application of such improved methods significantly increases the accuracy and usefulness of the findings relative to past efforts. Second, because of the central role of Soviet geologists in the past and the uncertain access to such persons, there is suspicion that the existing reporting is incomplete, and important positive findings have been concealed. Third, the development of competent exploration geologists takes many years and requires building a training capacity at the university level. Delaying such training could put off indefinitely the chance to develop Afghanistan's own capacity for exploration and the management of subsequent exploitation operations. It should be recognized that the scientific information-on which the development of the minerals sector rests-has its own internal need for revitalization. That body of information must be re-examined periodically. Existing information is likely to be neglected, discredited, or forgotten.

Some elements of training programs should be linked to the specific needs of the particular strategy chosen for the development of the minerals sector. However, training of geologists, geochemists, and geophysicists should be largely independent of the strategy selected. Ultimately, the international strategy is likely to prevail. It may take decades for the feasibility of this strategy to be demonstrated and translated into a substantial investment program for the full-scale exploitation of the sector's resources. Still, there 
are compelling reasons for continuing the exploratory work at an intensive level. Precisely because foreign investment will be required to develop Afghanistan's minerals sector, Afghans should be trained to participate in and ultimately manage its development. The better the technical training of Afghans who participate in the process, and the greater their numbers, competence, and experience, the easier it will be to assure that development of the minerals sector will serve the mutual interests of investors and the Afghan nation.

Providing for basic energy needs is a matter of major importance to Afghanistan, quite apart from the exploitation strategy chosen. The basic energy needs of the population (particularly for cooking and home heating) are considerable. The extent to which such needs are fulfilled will have significant impacts on health, sanitation, and the environment. Because the population of Afghanistan is so dispersed, provision of energy-especially to rural people-should be undertaken within a decentralized framework.

\section{National Strategy}

The national, or inward-looking, strategy for mineral development focuses on exploitation of mineral resources primarily to meet the needs of domestic markets. The principal concern of this strategy is developing sources of domestic energy and raw materials for fertilizer production. Export markets for natural gas and gemstones will remain important. Revision of laws and regulations on minerals rights, training, and exploration programs should be undertaken with the idea of building a foundation that will enable Afghanistan to shift to a regional or international strategy as it becomes appropriate.

In the long run, the growth of demand for mineral products and energy will largely be linked to the overall economic growth rate and to the requirements of refugee resettlement. Because Afghanistan's income is low and the economy lacks a dynamic growth sector, the growth rate of the economy may well remain low over the next decade. Hence the pace of development of mineral resources is likely to be modest under the national strategy. The investment requirements to meet demands for mining and energy products will be limited. Most of the available resources will be used for providing energy, which will necessitate some investments in that sector. However, additional funds will be needed to support exploration and training. With low savings, the Afghan government will likely have to turn to bilateral and multilateral sources for the funds to carry out this development.

The principal components of the national strategy are set out in the following paragraphs. 


\section{Development of Gas and Petroleum Resources for Domestic Consumption}

Even before the Soviet invasion, the development of Afghanistan's natural gas resources focused on exports to the Soviet Union. Afghanistan imported most of its gasoline and other petroleum products from the USSR. The USSR accelerated natural gas shipments following its invasion of Afghanistan, but Resistance activity ultimately put an end to these exports. ${ }^{4}$ The future of this trade is in doubt because of Afghan dissatisfaction with Soviet pricing and metering in the past and because volatile economic and political conditions in the states of the former Soviet Union may delay resumption.

Three construction projects aimed at providing Afghanistan with greater self-sufficiency in its energy subsector merit early consideration:

- A pipeline for natural gas from the production fields to Kabul;

- A refinery to process Afghan crude petroleum; and

- Electricity-generating facilities for the Kabul area using natural gas as a feedstock.

Construction of a pipeline for natural gas from the production fields to Kabul will permit the use of natural gas for the city's day-to-day energy needs. The feasibility of such a pipeline remains to be evaluated. The central question is whether there is sufficient demand for natural gas at a price that covers the costs of production and distribution. Because price information on alternative markets is suspect (the opportunity cost is not well defined because the only purchaser has been the USSR), it is difficult to provide a meaningful analysis of the economic feasibility. If trade with the USSR in natural gas once again becomes possible, the opportunity cost will rise again. The other important consideration is the level of demand by industry for energy and by households for heat and cooking. The latter is currently quite low and will expand only with growth of incomes and as households are connected to the gas mains.

An alternative or supplementary approach is to commence the marketing of bottled natural gas in Kabul. Such an effort would reveal the prospective size and rate of expansion of the market and provide the basis

\footnotetext{
${ }^{4}$ The Kabul Times account of an interview with Abdul Samad Saleh, Minister of Mines and Industry, reported on May 15, 1991, that the commission for Afghan-Soviet technical and economic cooperation agreed that the export of natural gas to the Soviet Union, at world prices, would be resumed "shortly after the arrival of a certain number of experts."
} 
for a decision on a pipeline to Kabul. Hence, the interim solution is to rehabilitate, and expand if necessary, facilities for bottling the gas, using private transport companies for distribution. When demand in Kabul indicates that construction of the pipeline should commence, the bottled gas can be distributed to other locations. Such a staged approach, first concentrating on the investment in adequate bottling facilities for the Kabul market and then building the pipeline when demand is adequate, is likely to be the cost effective solution for the next 5 years.

Construction of a refinery to process Afghan crude petroleum can save Afghanistan considerable foreign exchange. Limited information is available on the petroleum reserves in Afghanistan. Despite Soviet reservations concerning the project in the past, there may well be sufficient reserves to justify the construction of a refinery to serve the domestic economy. Analyses of the feasibility of such a refinery and the suitability of Afghan crudes need to be undertaken as soon as the political situation permits.

Construction of electricity-generating facilities for the Kabul area using natural gas as a feedstock should be considered as a part of a program of energy production and distribution for localities. As areas of Afghanistan become sufficiently calm to permit a return to normal economic activity, providing electricity should become a priority goal of government. A plan for the Kabul area should identify the present gap between long-term supply and demand and examine the alternative methods of increasing supply. Natural gas has particular merit because it may be possible to expand the generating capacity in small increments.

A fourth project, rehabilitation and expansion of the fertilizer factory at Mazar-e-Sharif, will also be a high priority because of the food needs of returning refugees and the importance of nitrogenous fertilizers in the production of wheat and other crops. The Mazar-e-Sharif fertilizer plant, which started operations in 1970s, uses natural gas as a feedstock to produce urea. Its original capacity was rated at 100,000 MT a year. The plant reportedly produced at full capacity during the early years of the war. More recently, it has been operating well below rated capacity because of a lack of spare parts and technicians.

\section{Electric Power Supply}

Availability of electric power will have an important influence on postwar rehabilitation. Little is known about the condition of existing facilities or the cost and time needed for their rehabilitation. Some sources indicate that electrical energy production has been steady at 1 billion $\mathrm{kW}$ hours over the past decade. This suggests that existing capacity is under strain either from war damage or because investments in generating capacity have not kept up with demand. Despite the war and the massive exodus of refugees from the country, city populations have substantially increased. It is likely that 
the demand for electricity, which exists mainly in the cities, is not being fulfilled because of poor operational characteristics and deterioration of the existing distribution system.

Expansion of the delivered electricity supply should be a high priority following resettlement. Available data indicate that most of Afghanistan's capacity is hydroelectric, followed by diesel and natural-gas-generated power.

Kabul is far better served with electric power than are other areas. Political and economic considerations may well require that other areas of the country receive more equitable treatment as rehabilitation and expansion programs get under way. Installation of minihydro facilities shauld be considered to supplement the rehabilitation and upgrading of existing plants and distribution systems. These two measures are put forward as part of the national strategy, but they should be placed high on the agenda for the energy subsector regardless of the mineral development strategy selected.

Rehabilitation of existing plant system and upgrading of distribution systems is a standard approach to postwar reconstruction where widespread damage has been inflicted. The status of much of Afghanistan's existing plant and distribution systems is unknown. Therefore, the first task is to carry out the needed surveys and identify the steps necessary to increase generating capacity and production from existing capacity and identify high priority improvements in distributions systems. It will be particularly important to reduce system loss-which is probably quite high-and to repair major damage. Priorities should be set for repair or expansion based on demand and alternative supply source.

Identification and installation of sites for new minihydro schemes should receive careful consideration. A considerable number of these generating facilities have been installed in Pakistan in the Northwest Frontier Province. The experience of the staff there can be used to enhance the development of a similar program in Afghanistan. The aim will be to provide electricity first to those areas that meet Mission-established criteria. Given the probability that control of Afghanistan will be fragmented and decentralized for the next several years, the feasibility of one or more large generating projects feeding into a national distribution network is doubtful. Instead, there is an opportunity to develop a decentralized system using hydroelectric energy.

In general, minihydro schemes trade higher capital costs for lower operating costs. Making electricity available in currently unserved or underserved areas will greatly benefit the political and economic development of the country. It can encourage light manufacturing and service establishments to become more productive. More jobs and income can in turn lead to improvements in the provision of educational and medical services. 
Transmission of energy from Kajakai to Kabul should also be considered. There is room for the installation of additional transmission capacity at the Kajakai Dam on the Helmand River. Installation of such capacity and the construction of a transmission line from Kajakai to Kabul could serve the needs of many villages and farms in areas where minihydro schemes are not feasible.

Despite proposals, however, the optimal long-term development pattern for the electric power generation sector is difficult to predict. As an integrated national posture is restored and as the economy expands, a centralized program exploiting natural gas and coal deposits and large hydroelectricity sites might prove optimal. It will probably be many years before such a centralized scheme is feasible. Further, it is conceivable that minihydro projects may be superior in the long run as well as the short run. Minihydro stations not only have advantages of low operating costs, but they also provide strong motivation for local users to maintain and protect the plant. The costs per $\mathrm{kW}$ hours are still a subject of debate among experts, but these costs may be competitive with those of large plants, especially where demand for electricity may lag behind the growth of generating capacity associated with large generating facilities.

\section{Energy for Cooking and Heating}

Wood is the traditional source of fuel, particularly in rural areas. However, with the stock of trees suitable for firewood declining, the difficulty of abtaining fuel is increasing and the supply of wood declining further. Two mitigating factors may have resulted temporarily in lower demand for firewood. First, the outflow of persons to urban areas as well as to Pakistan and Iran has reduced the rural populations, and with higher death rates caused by the war, the current number of persons in the countryside may be somewhat below the levels of 15 years ago. Second, the much-increased urban populations may have been using fuels other than wood.

Coal is also used for household heating and cooking, but the amounts available are limited. Currently, about $150,000 \mathrm{MT}$ of coal are produced. In the past, household use took about 40 percent of that total, or 60,000 MT.

Assuming that household use is $75,000 \mathrm{MT}$-and using very low consumption figures-1.5 to 2 million persons can be supplied with coal for heating and cooking.

With the return of the, refugees there will be added pressure on the fuel supply. Inevitably, there will be more rapid cutting of trees for firewood. It is difficult to foresee what prompt and effective action could stem this damage. Use of coal can be increased through the manufacture of briquettes, and the demand forces of the economy should lead to greater coal mining 
and improved distribution in urban areas. However, rural areas are likely to rely on firewood into the indefinite future.

Programs in this area should include replanting of trees in villages and along rural roads, improved management of the forests, initiation of major reforestation programs, analysis of feasibility of briquette factories, review of procedures for expansion of coal mining, and hydroelectric projects.

Solar and other unconventional energy sources should be explored, but are not likely to develop significantly in Afghanistan over the next decade. Low income levels and other pressing investment requirements suggest that reliance on firewood will continue with an increasing use of coal in urban areas.

\section{Energy for Agriculture}

Although much irrigation in Afghanistan is gravity fed, the use of diesel pumps is a necessary, albeit costly, adjunct. In Pakistan, the availability of electricity offers a cost-effective energy source for irrigation that is not currently available in Afghanistan. Rural electrification should be considered in regions of sufficiently dense agricultural activity. Most of the electrical pumps used for irrigation in Pakistan have high capacities. Most are connected with large surface-irrigation projects or with large tracts of privately held land. Demand for electrical and petroleum-derived energy is relatively low compared to other uses. However, pumping water can be critically important to irrigated agriculture in Afghanistan, and energy supplies for pumping deserve careful attention.

Energy for land cultivation is an important input for agricultural development. Availability of diesel fuel at the right times and places can promote the use of tractors and allow more extensive cultivation. Energy is also needed to transport agricultural inputs to farms and crops to market.

Needs for tractors will depend critically on the extent to which draft animals are available. Survey work carried out by the Swedish Committee for Afghanistan has indicated an apparent critical shortage of animals for field preparation and a need to introduce a substantial fleet of tractors to replace animals. This conclusion is controversial, but as the actual situation becomes clearer over the next few years, the extent of the need for tractors will also become clearer.

The ease and cost of fuel delivery are critical considerations. An effective fuel distribution system can be anticipated if there is an adequate road system with ownership of trucks widespread rather than concentrated in the hands. of a few government or quasi-government organizations. Improvement of the road system will be a protracted process. The organization of the transport industry is important and every effort should be 
made to block the emergence of monopolistic transport firms. During the evolution of Afghan's political economy, there may be attempts to create monopolistic firms either by awarding large contracts to favored persons or by other means. The more competitive Afghanistan's transport industry, the more effective it will be in providing fuel for agriculture where it is needed.

\section{Exploiting Other Mineral Resources}

Apart from energy-related development, only limited opportunities for major mineral projects exist under the national strategy. Nevertheless, mining by small-scale enterprises should be encouraged. Much of the current production consists of gemstones for export to foreign markets, which might not be considered truly inward-looking or "national" in character. These endeavors are included because they are traditional, labor intensive, and within the skills of the present labor force; require limited capital; and will develop readily within the environment of a market economy.

Precious and semiprecious gems have long been mined in and exported from Afghanistan, particularly lapis lazuli and emeralds. Such activities have continued throughout the war period and should be encouraged. Emeralds have been exported by individuals in a less-organized market. There may be opportunities to expand production and marketing of these gems as hostilities decline. The government should not be expected to be capable of exercising much control over these parts of the economy. Instead, the government should focus on a strategy for facilitating private initiative.

Particular projects in this area might include the development of one or more financial facilities for lending to small mining and trading operations. Another option could be the establishment of an Afghanistan Gemstone Corporation to function like the existing Pakistan Gemstone Corporation which trades on world markets and purchases output of small miners and traders. Such activities should be self-financing. There is no justification for subsidizing this sector. The interest rates charged for loans should reflect market conditions, and the fees charged by the corporation should cover all costs.

\section{Mineral Law and Rights}

In order to develop mineral resources under this national strategy, it will be necessary to revise laws that restrict ownership of mineral rights, including rights to hydrocarbon resources. Mineral rights should be well defined. In particular, procedures for sale and transfer of such rights must be clear to all involved and not unduly complex and restrictive. Even if Afghanistan begins with an inward-looking or national strategy, a clear legal framework for attracting foreign investment should be established. 
The procedures for mineral rights should be simple, and the government should do what it can to encourage a market in such rights. One important requirement is to define explicitly the mineral rights that can be held by foreigners, directly or indirectly. The definition must prevent foreign control of mineral rights from becoming too extensive to be politically acceptable. At the same time, the definition of these rights should be sufficiently favorable to encourage foreign investment.

A second important area of mineral law should establish reasonable government fees and royalties. These should be set at levels that are nondiscriminatory and legally enforceable and that encourage investment by the private sector.

The fees must be sufficient to pay the costs of the government's contributions to the mineral development program. A rate that balances costs and fees may be difficult to determine. Best effort approximations may be sufficient at first, but the principles underlying the establishment of fees must be made clear in the policies and regulations adopted.

The national strategy should contemplate modest levels of foreign investment. There is a strong case for codifying the approach to granting mineral concessions to foreign investors at the time that mineral laws and rights are revised. The approach to mineral law should be comprehensive so that a complete code can be formulated covering the issues likely to arise under other strategies.

The role of foreign investors in the minerals sector is bound to be a sensitive subject in Afghanistan for some time. The country has had an unfortunate history of exploitation by the Soviet Union, frustration over arrangements with foreign companies, and disparagement of the role of international private investors. Given these experiences and traditional attitudes toward outsiders, the idea of large-scale and early foreign investment in the minerals sector is unlikely to be accepted easily. Nevertheless, private foreign investment in Afghanistan's mineral resources will be a key to the long-term development of the sector. Hence the legal framework for foreign investment should be open, nondiscriminatory, and attractive from the start.

\section{Training and Exploration}

On the surface, it might appear that a training and exploration effort is not a large or urgent requirement under the national strategy. A prospective natural gas surplus of large dimensions looms until and unless new arrangements for the export of natural gas are made with the Soviet Union or facilities are established for distributing natural gas in the domestic market. No formal exploration program for gemstones is needed. The locations of coal resources for increased mining appear to be known (the 
volumes being extracted are minuscule compared with reserves). However, training for operation of the gas fields will be needed. Implementation of specific projects such as the creation of a gemstone corporation, the revision of the legal framework for mining, and the establishment of a specialized lending facility for small-scale mining and mineral trading may all require specific short-run training efforts. Most important, considerations of strategic flexibility in combination with the lengthy training of professionals warrant high priority for beginning at this time the training of a cadre of capable Afghans in mineral exploration and exploitation skills.

Geologists, mining engineers, and other technical personnel must be developed to provide the framework for an eventual shift to other strategies. If there is any expectation of more aggressive exploitation of minerals, the case for this is very strong. With a cadre of specialists able to deal with the technical issues and to discuss with their foreign counterparts the resource situation, the outcome of Afghanistan's negotiations with foreign investors and importers is more likely to favor the country's interests. Furthermore, as foreign investors enter, these trained Afghans will be employed in important positions in the newly formed companies and more of the value added will accrue to Afghans. Without the development of skilled Afghans, foreigners inevitably will occupy most of the higher management positions in these companies in which many key exploitation decisions may be made.

Moreover, exploration may reveal opportunities suitable for development as part of a national strategy. For example, if exploitable deposits of phosphate could be found, Afghanistan could free itself of the necessity to import DAP fertilizers, save foreign exchange, and contribute to the development of agriculture. For these reasons a major training program in selected fields is indicated even under the national strategy.

The two main tasks to achieve are as follows.

The Afghan geological survey should be strengthened through programs of institutional development and training.

This is probably best done through a multilateral pool arrangement among donors. A.I.D. and the Afghan government should avoid a situation in which each donor takes part of the program in an uncoordinated manner driven by potential commercial interests. Unlike some other donors, A.I.D. does not usually make available foreign assistance for the purpose of promoting U.S. foreign investment. Accordingly, it is to the advantage of U.S. mining companies, as well as in the best interests of Afghanistan, if assistance for geological surveys has no national biases. An attractive program will establish a pool of investment funds to be contributed by all major donors. These funds can then be systematically used for agreed-on purposes, with all results open to the participating countries. The funds 
would be used to finance explorations carried out by individual geologists, geological consulting firms, and exploration units of mining and other resource development companies, with suitable limitations and safeguards established in advance. A mining company that wanted to keep the results of its investigation out of the public domain would bear the full costs of exploration. However, even in this case, conditions included in the company's agreement with the government would require that the information obtained from exploration be released into the public domain unless the company followed up its exploration with investment within a stated time. The rules for operating the multilateral pool arrangement would provide opportunities to support the government's own exploration activities. as well as the work of mining companies and geologists approved by the government. These funds could also support overseas training, equipment procurement, and library acquisitions.

- A university faculty should be developed to teach geology and mining engineering.

Emphasis should be on practical courses with the objective of providing both foreign investors and the Afghan geological survey with well-prepared Afghan scientific and management staff. Again this calls for an institutional development program with major investments in faculty development. The goal is to reach acceptable international standards so that graduates can gain onthe-job experience through temporary employment with international mining companies. Such a project is best approached on a multilateral basis to ensure adequate resources for training. Afghanistan has a history of identifying particular Afghan institutions with certain countries; this has not worked well. In the emerging Afghanistan, a different, multilateral approach may prove more successful.

\section{Conclusion}

The national strategy focuses on initiatives initially designed to serve domestic needs. The legal framework that governs Afghanistan's minerals sector should be revised. Exploration activity should be renewed. Important training programs should be mounted. Implementation of the national strategy might start on a decentralized, cross-border basis, even before there is a new national government. A well-conceived program of investment in minihydro stations can make a contribution to rapid development in local areas where they prove suitable. Such a program should be aimed at providing electricity first to those areas that meet community control and other Mission-established criteria. 


\section{Regional Strategy}

The regional strategy for development of the minerals sector in Afghanistan concentrates on mineral and energy projects that will sell much of their output to Pakistan, Iran, and the USSR. The regional strategy is more complex and expensive than the national strategy, but it also can make a major contribution to Afghanistan's economic growth. However, the regional strategy requires much less investment than the international strategy that is described later in this chapter.

The political complexity of relationships among the countries concerned and the long record of distrust among them might make it difficult to execute the regional strategy. Nevertheless, economic cooperation among the neighboring countries would bring significant advantages and mutual benefits to all.

Afghanistan might have difficulty in regional negotiations unless it receives support from the United States and other influential nations. On the other hand, international involvement might not be desirable. This report makes no judgment on the point. Regardless, agreement among the neighboring nations themselves is essential to the success of the regional strategy.

Within the national strategy, the planning and implementation of a number of projects can start at once. By contrast, the initiatives described below can only begin when the political situation within Afghanistan is resolved and there is a government capable of undertaking continuing international negotiations.

\section{Natural Gas Sales to the USSR}

Before the Soviet invasion, natural gas sent via pipeline to the USSR accounted for a major share of Afghanistan's exports. However, artificially low prices paid by the Soviets and highly questionable unilateral metering practices used by the Soviets have been severely criticized by knowledgeable Afghans. On the basis of conditions now prevailing in the Soviet Union, it is very difficult to predict whether and how this trade could resume.

If circumstances for a resumption of the trade seem favorable, a new Afghan government should organize a working group to evaluate prospects and recommend steps to be taken to ensure that the Afghan people benefit from the export of their natural gas resources. Before entering negotiations, this group should seek assistance form internationally recognized financial and technical advisers who can help formulate negotiating strategies and policy positions. 


\section{Fertilizer Production}

At present the urea fertilizer production from the plant fed by natural gas at Mazar-e-Sinarif is aimed at the domestic market. There may be opportunities to produce fertilizer for sale to the regional markets. Such export production of fertilizer can best be undertaken once the issue of Soviet gas sales has been resolved. The government can allocate the available natural gas among the highest return uses. For regional fertilizer sales, the question is price-urea from natural gas is produced in several countries including the main regional markets-and it is uncertain whether Afghanistan can compete effectively. Transportation costs may be a key variable. The Kabul government reportedly provided some exports of urea to North Korea, but it is not clear that this trade had an economic foundation.

A new Government of Afghanistan should undertake an analysis of the fertilizer demand and supply in the region to determine whether there is room for sizeable and sustained urea exports to its neighbors and whether such exports can be marketed at likely production costs. Both Iran and. Pakistan are major producers of natural gas and both tend to intervene with major industries, so the prospects for Afghanistan may not be bright. However, Soviet markets might be served successfully.

\section{Electricity Production}

Production of electricity for sale to other countries in the region can use either natural gas or coal as a fuel. In addition there are potential hydroelectric sites of sufficient size to make exports of electric power feasible. At present Afghanistan has an electricity-generating capacity of 400 MW representing relatively small projects by current standards. A large modern generating plant based on coal, natural gas, or hydroelectricity will need to be able to export a substantial portion of its output. The focus here is on the use of natural gas or coal, not hydroelectricity, for generating electricity for export.

The first matter is to identify potential customers. The primary candidate appears to be Pakistan. It may prove feasible to develop an electricity source whose specific purpose is to supply Pakistan's power grid. In principle, the Pakistan authorities are prepared to purchase electricity from the private sector, and they have at least one internal project close to acceptance. If Pakistan proves willing to purchase electricity produced in Afghanistan, the issue of the preferable fuel can be tackled. However, Pakistan may prefer to purchase coal or natural gas for its own power plants-even though the transport costs of fuel are greater than the costs and losses of transmitting electricity.

Pakistan's burgeoning population and expanding industry have put increasingly severe strains on its electric power supply. The power 
authorities have not been able to produce enough electricity to meet the needs of the economy, resulting in frequent power outages. Many industries have invested in expensive standby power-generating capacity. Power shortages also have limited the ability of the authorities to extend electricity supply to more rural areas. Pakistan's power supply is limited and erratic.

In 1983 Pakistan had about 4,500 MW of capacity of which 55 percent were hydroelectric. The hydropower originates from two multipurpose dams. The generating capacity of these dams has been expanded significantly during the last decade. However, it appears that the power situation has not improved. In response to the growing difficulties in financing new sources of power, the Pakistan government announced in 1984 its willingness to allow private companies to build and operate power stations for sale to the power authorities. So far this change in policy has shown only limited results.

Given these circumstances, the merits of Afghanistan borrowing money to build and operate generating facilities with sale of the electricity depends on three conditions:

1. Afghanistan's ability to generate the electricity more cheaply than the long-run marginal cost to Pakistan of expanding its capacity, which depends on the size of the facility and the cost of the fuel.

2. The combined transport cost of fuel and power under various alternatives.

3. The cost of the capital available to the two countries.

In effect, by providing low-interest capital to finance Afghanistan ventures, the suppliers of the credit can enable Pakistan to acquire cheaper power and Afghanistan to earn foreign exchange.

Neither Iran nor the Soviet Union is likely to purchase electricity from Afghanistan. Iran apparently has no shortage of energy sources. The USSR's electricity situation is uncertain, but if the economy continues to decline an energy shortage is unlikely to be an immediate problem. At present Afghanistan imports electricity from the USSR. A preliminary conclusion is that, with the exception of Pakistan, regional markets for electricity are not promising over the next decade.

A final question regarding the sale of power to Pakistan is whether the prospects for payment are reasonably good. Pakistan has very little foreign exchange and might try to finance the purchase of electricity through some type of barter trade. Any such idea should be resisted; a significant part of Afghanistan's costs will be in foreign exchange, and the economy should not be tied up in a number of special arrangements where prices are not free to adjust to conditions in international markets. 
The implementation of the regional strategy will require access to substantial funding-presumably through the international development banks and perhaps the national development banks of participating countries. Loans would be based on successful negotiation of sales agreements with neighboring countries. None of these countries currently has a strong economy. Making such arrangements might prove difficult but superior to prolonged foreign support of an Afghanistan unable to earn foreign exchange in any way other than agriculture and the export of natural gas to the Soviet Union.

\section{Conclusion}

A new Government of Afghanistan should explore the possibility of collaborative projects with its neighbors. If there is interest, complex technical and economic assessments can be made. Because international development banks are a natural source of finance for such projects, their interest should also be explored at an early stage. Prospects include sales of electricity and fertilizer as well as natural gas.

\section{International Strategy}

A minerals development strategy aimed at serving international markets is designed to achieve rapid exploitation of Afghanistan's mineral resources by permitting international mining and petroleum corporations to provide capital and technology to develop such resources. The government's responsibility will be to train Afghan manpower to provide engineering and management services to such mining and petroleum operations. The point is to build up as much value added by Afghan factors of production as possible. Because only limited Afghan capital inputs are likely to be available, most of this added value will represent either rents or royalties for the mineral rights or inputs of manual, technical, and professional labor services.

The premises of the international strategy are as follows.

- Involvement of foreign petroleum and mining companies in the exploration and exploitation of Afghanistan's mineral resources and

- Attention to social equity in the distribution of the benefits of minerals development.

Domestic or national resources are unlikely to provide sufficient capital to finance even moderately-sized projects to export minerals to world markets. Nor is it likely that large sums can be borrowed from international banks or other governments for such purposes. To make significant progress in sales on international markets over the next decade, Afghanistan will have 
to turn to private international mining and petroleum companies to mobilize the required capital. In addition to funding for plants and equipment, Afghanistan needs the technical expertise, marketing channels, and management know-how that such companies provide. If Afghanistan attempts to develop its mineral resources for international markets, there appears to be no alternative to seeking private foreign investment to finance the projects.

Afghanistan's history of assertive nationalism suggests that successful foreign investment in mining can only be achieved if the various elements of Afghan society agree to pursue this goal based on a reasonably equitable distribution of benefits. Without such a consensus, conflicts and difficulties will bedevil both the construction and operation of the mines. Such problems will quickly bring an end to infusions of private foreign capital. Therefore, the international strategy can only be pursued by a government prepared to develop and maintain the required domestic support and will last only if the benefits of the strategy are fairly shared.

To maximize the long-term benefits to Afghanistan of the international minerals development strategy, training and exploration programs are needed. These were introduced in the discussion of the national policy earlier in this chapter. The training of Afghan technicians, geologists, mining engineers, railway construction and maintenance engineers, and managers should be the highest priority program. A fair share of the value added in these sectors should flow to Afghanistan nationals, and this can be achieved only through a vigorous training program.

Afghanistan's mineral resources are important national assets whose present value to the country's economy should be maximized in the light of balanced techno-economic judgments concerning future opportunities and risks. The time factor is critical. Whether to begin promptly or delay the development for some years given the state of knowledge and the state of the market is the central and perennially difficult decision. Politically or ideologically based investment decisions are hazardous and often wrong.

It may be worth waiting if the value of the resources is likely to increase faster than the long-run rate of return on general investments. On the other hand, Afghanistan needs to accelerate its economic development in view of its population growth and its lag behind most developing countries in levels of productivity, living standards, and investment. Rapid developments in materials science and biology have caused the value of some raw materials to decline. That trend may well erode some of the long-term demand for traditional mineral products. This consideration suggests that prompt exploitation of these resources is merited. A waiting strategy on minerals development has considerable risks, and an inactive leadership may awake only to find that the world economy has moved on. What was once a desirable asset may no longer be so valuable in future decades, and an opportunity to lay the groundwork for self-sustaining national development might be lost. Afghanistan's mineral resources presently appear to have more 
potential for rapidly expanding the national economy than do some other investment areas. Hence, it is important to formulate a strategy that takes the possible erosion of that potential into account.

The international strategy cannot be executed in the present political environment. Nevertheless, because this strategy has significant potential for contributing to the development of a self-sustaining economy, it is important to consider the requirements of the international strategy now. With these requirements in mind, other strategies can be used to lay building blocks that will permit future leaders to mobilize the resources needed for large-scale mineral and hydrocarbon projects. The major targets for development are presented in the following table.

\begin{tabular}{ll} 
Resource & \multicolumn{1}{c}{ Target } \\
Coal & $\begin{array}{l}\text { Electricity generation for internal use and regional export } \\
\text { World markets }\end{array}$ \\
Natural gas & $\begin{array}{l}\text { Electricity generation for national use and regional export } \\
\text { Fertilizer-world markets }\end{array}$ \\
Iron ore & World markets \\
Copper ore & World markets \\
Other ores & World markets \\
Gems & World markets
\end{tabular}

The full exploitation of coal, iron ore, copper, and other metallic and nonmetallic ores requires the construction of a railway within Afghanistan and access to suitable port facilities in a neighboring country. Because of the long hauls and Afghanistan's difficult topography, a substantial large volume of ore must be exploited to keep the transport system cost to an acceptable level.

Potential impacts of mineral extraction operations on Afghanistan's land and water resources deserve careful attention, at the start and during mining activities. For example, water used for beneficiation of ore and improper disposal of tailings leftover from mining activities can pollute streams and reduce the productivity of agricultural land. These negative impacts can be avoided by following environmentally sound mining methods, such as evaporation of beneficiation water in lined ponds and establishment of proper sites for disposal of tailings. Such methods, which are well-known to Western mining companies, should be incorporated into plans and agreements. 


\section{Organization of Ministry of Mining and Petroleum}

A preliminary study should be carried out covering the organization, functions, and staffing of the Ministry assigned the responsibility of developing the mining and energy resources of Afghanistan. The scope and activities of this Ministry depend critically on the strategy the government selects. Assuming that the international strategy is being followed, the organization is particularly important because it must develop and deal with a complex financial and technical program. The senior officers of this Ministry should encourage and nurture foreign and Afghan private sector investment while simultaneously playing a guiding and regulatory role.

\section{Legal framework}

Existing law defining the role of foreign investors and participation by the government must be carefully reviewed. The Afghan people must be assured a fair share of the value of the mineral resources exploited, and the prospective returns to the mining companies must be sufficient to provide attractive investment opportunities for multinational companies. The returns required by foreign investors are conditioned by two underlying considerations: the alternative risk-free real returns that are available and adequate rewards for the commercial risks carried. Commercial risks essentially relate to the quality and quantity of accessible reserves and to the possibility that there will be deleterious interference in the operation of mines. The' mining laws must provide favorable initial opportunities for the mining companies to compensate for the high commercial risks.

In revising the mining laws, it is necessary to develop an appropriate approach for both natural gas/petroleum and ores. In developing these conditions, two types of royalties for ores should be considered. One will be fixed by the government. The other will involve competitive bidding on concessions. They can be combined in a two-tier system whereby the government sets the minimum level of royalties it needs to earn and aims the second tier at the highest level obtainable from foreign investors.

The mining laws should define the procedures for determining concession grants as well as the rights and responsibilities of the government and the concession holder. The mining laws include model concession agreements and require that the granting of concessions be managed openly.

To assist the government in the execution of this legal review and the rewriting of legislation, the government should appoint a high level committee to prepare the legislation. Recognized technical experts should support the committee. The issues to be covered are the new laws for hydrocarbon drilling and mineral exploration and production. Because all of this work must be accomplished before the international strategy can be put into effect, the sooner the preliminaries are started the better. After the technical work 
has been completed, one or more versions of the legislation should be forwarded to the responsible officials for review and comment. Consensus is an important part of the strategy formulation, so there should also be public discussion and debate on the issues.

\section{Transportation Studies}

The first step in developing the railway and port facilities required by the mineral and hydrocarbon development program is a careful technical study of the transport alternatives. There are four components to complete.

- Review alternative port sites in Iran and Pakistan for shipping ores including natural gas;

- Review alternate routes for rail connections from major ore sites to the ports;

- Estimate capital costs of construction of alternative transport routes; and

- Estimate total costs of products under varying assumptions concerning production locations, quantities, transportation charges, and returns on investment.

The three critical costs in the development of major mineral extraction projects are (1) the operating cost at the mine head or well head, (2) the transportation cost/MT, and (3) the capital cost/MT of the ore at the point of shiploading. The long haul from Afghanistan to the river ports of the Soviet Union or to the sea ports of Pakistan and Iran requires a large volume of ore to reduce the capital cost/MT. The more difficult the transportation situation, the lower the mine site cost must be to justify the high transport costs.

Although there was some study of the economics of a railroad to be financed by Iran before the overthrow of the Shah, little serious assessment has been done of the feasibility of the required combination rail-port improvements implied in the use of a railroad for moving ore through and out of Afghanistan. There are many complex issues involved in the ultimate design and construction of a transport system.

Reconnaissance work on the transport system should include consultation with appropriate authorities in Pakistan and Iran. Options for establishing connections with either or both countries should be assessed. Whether the Soviet Union should be considered as an alternative depends on presently unforeseeable developments. 
- The ultimate route selection requires analysis of how the railway can serve the country or countries through which it passes. This will involve careful negotiations and considerable technical analysis.

- Treaties must be designed to establish the rights Afghanistan will have in such a transport project. A properly formulated legal framework is essential, and the port and railway must be operated in a highly efficient manner. The entire process of managing the transport system, developing and integrating the bidding for mineral concessions, and determining the transport system costs should be worked out in detail and reviewed closely by the World Bank, the Asian Development Bank, and other development institutions that may provide financing. The involvement of these institutions will provide critically needed oversight on the quality of engineering and transport economics. These institutions can also serve as facilitators for negotiations with Pakistan or Iran.

The preliminary transport study should assess the techno-economic merits of alternative routings and identify a preferred route on the basis of minimum cost. With benefits likely to be fixed on the basis of traffic assumptions, the main question will be which route provides the cheapest total transport costs. After making that selection, the study should examine the integration of the chosen route with the transport configurations within Pakistan or Iran. Finally the integration of the minerals concessions bids into the financing of the transport system should be worked out with the development banks. This preliminary transport study is one of the critical steps that must be completed before the international strategy can proceed.

\section{Integration of Railway and Mining Development}

Facilitating the process by which international mining and petroleum companies choose to invest their capital in Afghanistan requires a careful coordination of the bids for exploration and exploitation with the financing of the railway/port system.

The design and bidding procedures will require careful consideration. One possible procedure that appears to be suitable under the circumstances is given here. The essential points are to carry out the entire process as openly as possible and to encourage maximum competition. The government should engage financial and exploration advisers to help solicit and analyze bids. The use of advisers will give bidders and development banks increased confidence in the integrity of the process and provide the government with an independent evaluation of the bids. 
Bidding will provide time for international mining or petroleum companies to study the tracts available for mineral or hydrocarbon exploration and exploitation. The country should be divided into appropriately sized areas for this purpose. Available geological information should be collated for each area. Companies interested in participating in the bidding should pay an appropriate entrance fee and have access to the data. Bids based on fees for the rights for a given time period and supplementary royalties for the exploitation carried out can then be accepted.

Areas will be assigned on the basis of the most favorable terms offered. After an agreed exploration period, the mining companies will submit their detailed exploitation proposals. These will be negotiated to reach agreement on the mining investments that will be made. The capital requirements will be provided by the mining company.

Because most exploitation is dependent on a transport system, the government should arrange to receive all exploitation proposals at one time. That will make clear whether there is sufficient demand to warrant a transport investment. Transport costs are largely fixed and the cost/MT associated with these fixed costs depends on how much tonnage is actually carried. By coordinating the bids for mineral exploitation, it should be feasible to match the transport costs with planned extractions.

The government should establish a state enterprise to operate the transport system. Because the system will involve two countries, a port, and a railway, the configuration of this enterprise must be established by treaty. The state enterprise can borrow needed capital and earmark its income to service debt from the construction of the transport system. The state enterprise should seek private sector financing for the design, construction, and operation, using a development bank as a lender of last resort.

Obviously putting into place a major mineral exploitation program requires careful coordination, support from the development banks, and the cooperation of friendly governments. Negotiations with Pakistan or Iran will be complex, but mutually beneficial transport projects may well prove feasible. For example, some of Pakistan's Baluchistan mineral resources could use parts of the same system; and port development or expansion could help Pakistan directly. However, neither the complexity of negotiations nor the time required for their successful completion should be underestimated.

Formally, the exploitable ore (MT/year) depends on fixed transport costs, variable transport costs, excavation costs, and beneficiation costs (plus smelting costs for copper). While mining companies can estimate the latter two costs, the former depend on the transport system. Variable cost estimates can be made on the basis of the length of the railway and standard parameters for port handling. The government will provide information to the mining companies regularly as the transport system develops. However, as previously stated, the fixed costs/MT depend on the 
In many areas of the world, mining companies construct and operate their own transport systems, eliminating dependency on host country systems. In Afghanistan, however, the cost of the transport system is so high that a single extraction project cannot bear the full costs. Moreover, Afghanistan is landlocked, and cooperation among national governments is essential to system efficiency and profitability. The haul to the ocean is long, and a need exists to construct extensive handling facilities. High fixed costs must be spread over as many tons of ore and other goods as possible. The railroad system may carry heavy commodities such as agricultural inputs, construction materials; and agricultural exports, as well as the products of Afghanistan's mines. The key to development of the minerals sector is coordinated investment in several mines, which will make the construction of the necessary transport system feasible. Conversely, the existence of such a transport system will make the investments possible. The challenge is to develop a method that protects the public interest while avoiding government involvement in day-to-day management (e.g., entering into a management contract with a private firm to staff and operate the railroad). Foreign minerals development firms can be expected to perceive political risks in transportationsystem investment in Afghanistan to be different, higher, and less controllable than those that apply to other countries in which they operate. These include investment size, payback period, number of long-term employees likely to be involved, extent of specialized commercial expertise needed to run a public utility, and uncertainties about relations between Aghanistan and the neighboring country through which the railway is to pass. The continuing cooperation of one of Afghanistan's neighbors will be needed to provide transit rights and ocean access. A well-designed minerals development scheme can be expected to garner substantial direct private investment. However, it is unlikely that an attractive total transportation and minerals development package can be put together without direct government ownership of the major transport component - at least to the extent of holding an initial majority share of the equity of the railroad system.

total extractions. The greater the supply of ore and the larger the volume of ore transported, the lower the price to the purchaser. The bidding/negotiation process is designed to deal with this situation.

The international strategy will require both major external funding and very careful management by the government, ${ }^{5}$ and it has many potential pitfalls. However, the international strategy may well offer the best chance to achieve a rising rate of economic growth through an export led development program in the next decade. Otherwise it can only be hoped that the

${ }^{5}$ In this context, "careful management by government" involves the intelligent, consistent, and determined execution of a sound policy, rather than the creation of a large government implementing or regulatory establishment. The key requirement is a resolute minister backed by the country's chief executive. Such circumstances have prevailed in Afghanistan in the past. An example is the successful creation of the Afghanistan Fertilizer Company in the early 1970s. 
agricultural sector will grow faster than the population. Without a substantial boost from the minerals sector, the economy may grow a bit faster than the agricultural sector, but continual balance of payments difficulties are likely.

\section{Training}

It cannot be overemphasized that a major training program will be required to develop the manpower skills to take full advantage of mineral resources. Rehabilitating the university training programs and linking them to graduate programs in Europe and the United States will provide an increased flow of talent. The university programs should take a long view, with early emphasis on building the teaching faculties and later turning toward the production of operational staff. The following should be noted:

- Training should be rigorous but practical with significant time devoted to obtaining experience in operational work.

- If the international strategy is followed, there will be a large demand for mining engineers as well as for railway engineers. The scale and scope of the training program will therefore depend on the strategy followed. However, the first years will offer the time and opportunity to build the institutions that will provide training, including the development of internships to permit realistic and practical on-the-job training.

\section{Exploration}

A major exploration program is needed to continue the work that has been done to date. This should ideally be done through a technical assistance program that includes geologists from countries that have acquired knowledge of Afghanistan's mineral resources as well as countries manifesting new interest. As envisioned, exploration will be carried out by many different organizations. Afghanistan's geological service must set the standards for exploration and catalogue the findings as they are made.

\section{Conclusions}

The international strategy is particularly attractive in that it holds out the possibility of accelerated economic growth that the other strategies are unlikely to yield. The international strategy is nevertheless a difficult one. It calls for (1) a complex process of concessions bidding coordinated with major borrowing to finance the transportation system, and (2) coordinating transportation system development with the neighboring country in which port and other transportation system improvements are required. Uncertain market conditions and transport costs mandate further study to determine the 
viability of investments. Most important in this strategy is the capacity of the government to move swiftly and with a politically well-defined program.

An expensive but otherwise attractive feature of the international strategy is that it is premised on expanding and improving Afghanistan's limited transportation system, thus reducing the costs of moving goods and substantially improving the country's access to the outside world. Such a transportation system improvement should encourage agricultural exports and improve the viability of a variety of private enterprise initiatives within Afghanistan.

The national strategy focuses on meeting some resettlement needs and prepares the way for more ambitious general development. The regional strategy, while seemingly less risky than the international strategy, is in fact hazardous due to the uncertain attitudes of Afghanistan's neighbors and the tenuous circumstances of their economies. The three alternatives represent the choices for Afghanistan's minerals sector.

What can A.I.D. do in the short run before there is a political settlement? The Mission should consider undertaking six principal activities at this time.

1. Facilitate the development of minihydroelectric plants.

Work on selection and design can begin at once and implementation can be achieved even before there is a political settlement.

2. Initiate work facility rehabilitation studies.

Rehabilitation studies would draw together all information on the current status of natural gas, fertilizer production, electric power, and other pertinent facilities and identify which are most in need of repair.

3. Initiate revision of mining and petroleum codes.

${ }^{6}$ O/AID/Rep has made the following comment on this list of activities for its consideration:

The suggested $\mathrm{O} / \mathrm{AID} / \mathrm{Rep}$ activities are probably too ambitious for the present...We may want to revisit these once we establish ourselves as a bilateral mission inside Afghanistan. Probably a useful course of action would be to train some Ministries of Mines and Industries staff members in World Bank-type courses to enable them to negotiate competently with exploration firms and banks. 
Respected Afghan engineers and attorneys can be assembled to work with foreign experts to draw up codes for consideration by a new government.

4. Prepare and initiate a training program.

Preparation of a training program to meet mineral sector needs could well fit into O/AID/Rep new Human Resource Development initiatives.

5. Prepare a mineral and petroleum exploration program.

A collaborative effort among Afghan professionals and foreign technical experts should define a renewed program of mineral exploration in Afghanistan, project costs of alternative levels of effort, and explore sources of funding.

6. Present seminars on mineral development to Afghan political and military leaders.

Seminars for Afghan leaders in areas where mineral development projects are likely to be located should emphasize legal, technical, financial, and other essential requirements for effective mineral resource development.

If projects, studies, and activities along these lines are undertaken in the near future, some of the preparatory work greatly needed by a new government will be launched. In the process, the likelihood that rational alternatives and recommendations for the development of the minerals sector can be presented to a new government at an early time will be greatly increased. In essence, what A.I.D. can do most effectively at this stage is to support the creation of the building blocks of a development program. With the building blocks in place and a settlement achieved, mineral sector development can move forward with the assistance of a variety of donors and international development agencies. 


\title{
Chapter 4
}

\section{AFGHANISTAN'S MINERAL RESOURCES: LOCATIONS, POTENTIALS, AND INFORMATION SOURCES}

\author{
Introduction
}

Previous chapters of this report have provided perspectives on the history of Afghanistan's minerals sector and alternative strategies for its future development. The present chapter summarizes the most recent available information on Afghanistan's mineral resources and identifies the principal sources from which more detailed information can be obtained.

More specifically, the chapter contains several resource maps and provides latitude/longitude data on Afghanistan's principal mineral deposits for inclusion in the O/AID/Rep's Geographic Information System. It focuses on natural resource availabilities of potential commercial significance: major deposits of metals and hydrocarbons, and principal hydroelectric power resources. The chapter identifies principal maps and surveys of Afghanistan's minerals published during the past two decades. Finally, it identifies other sources of information on Afghanistan's mineral resources that may be helpful to persons carrying out research in this area.

\section{Identity and Location of Afghanistan's Mineral Resources}

In this section, we present maps and a table that show the locations of Afghanistan's mineral resources.

Figure 1 provides a "School Map" suitable for inclusion in an introductory text for Afghan school children. This map has been provided in response to a Scope of Work requirement and represents a useful point of departure. It shows the locations of Afghanistan's most important mineral resources and is a simplified version of a complex mineral resource map. 


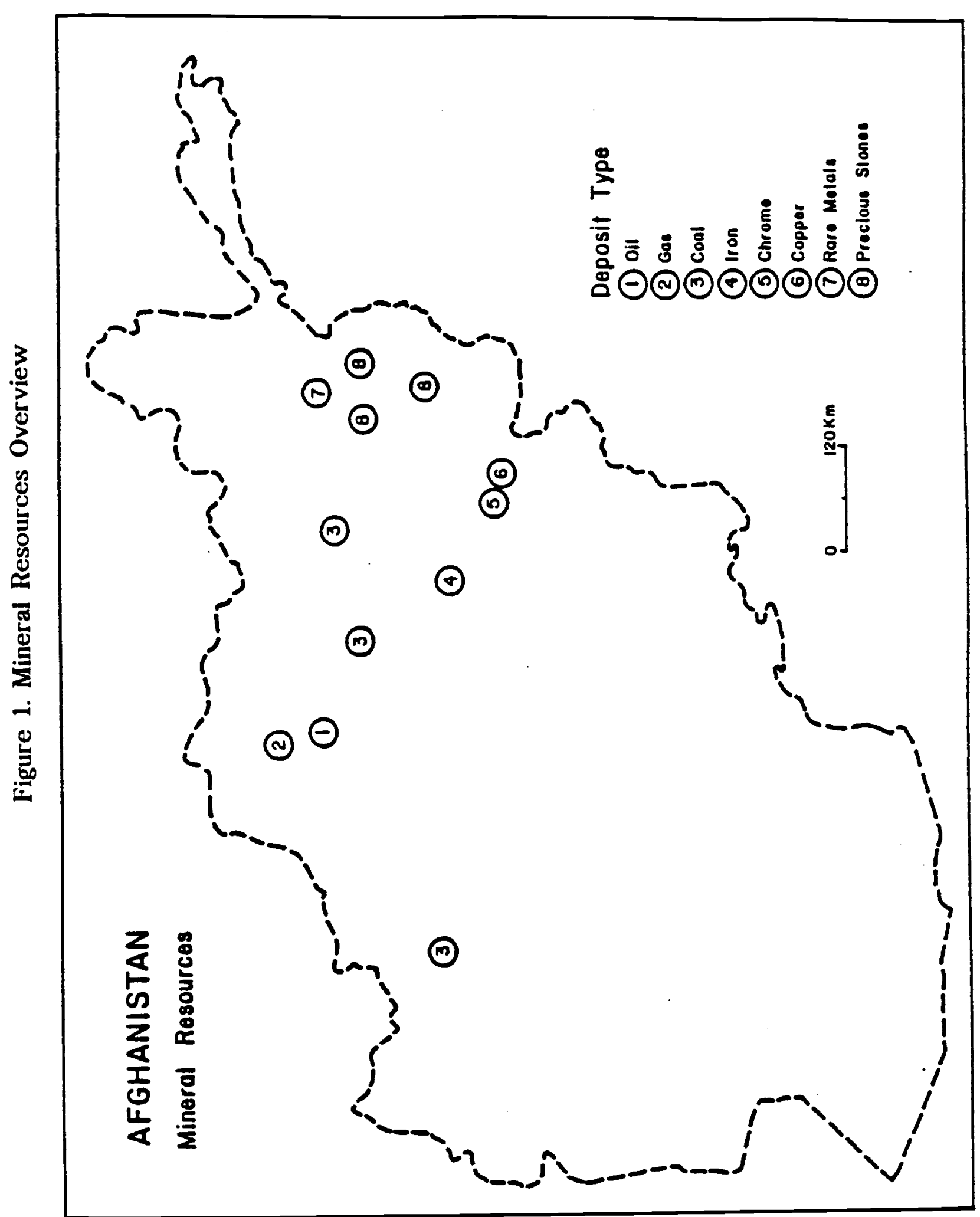


In order not to confuse students with the innumerable scattered sites of each resource, only the most important locations are presented on this map. For example, the many locations of precious stones in Nuristan, Panjsher, and Badakshan are symbolized by the general area marked off by \#7 (rare metals and earths) and \#8 (precious stones). Similarly \#2 (gas fields) symbolizes the many wells and $\# 3$ (coal) the deposits that are actually scattered in 36 locations across the north.

Names of the most significant mineral resource areas of Afghanistan are

- Angot oil;

- Sherberghan gas;

- Northern coal fields;

- Hajigak iron;

- Logar chrome;

- Ainak copper;

- Sar-i-Sang lapis lazuli;

- Panjsher emeralds;

- Sarobi rubies;

- Rare metal and rare earth pegmatites; and

- Nuristan tourmalines and kunzite.

Most deposits shown on Figure 1 are in the northern and northeastern sections of the country. This geographic clustering in some measure reflects past Soviet influence on Afghanistan's exploration priorities as well as the country's geologic endowment. The clustering will affect proposals for railroad and other transportation improvements. Topographic features of the country (not shown on the map) also are of critical importance to present and prospective transportation costs.

Figure 2 shows metallogenic areas (i.e., areas related to the origin of ores) and the locations of deposits by size. The map shows deposits of bauxite (aluminum), gold, tin, barite, lead, and zinc as well as the metals shown on the School Map.

Figure 3 shows hydrocarbon areas and locations. This figure distinguishes large and medium deposits from small deposits and shows peat as well as coal deposits. 


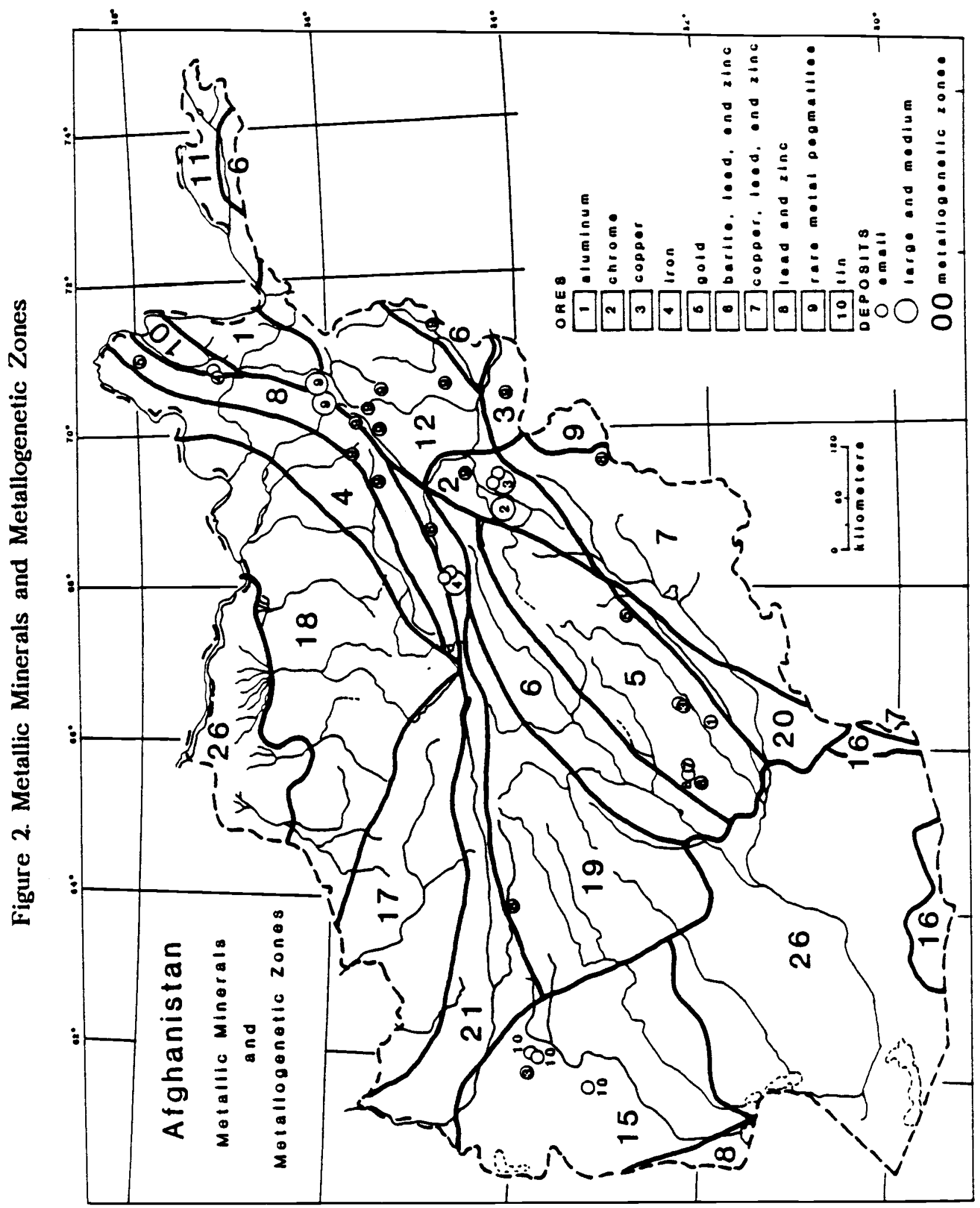




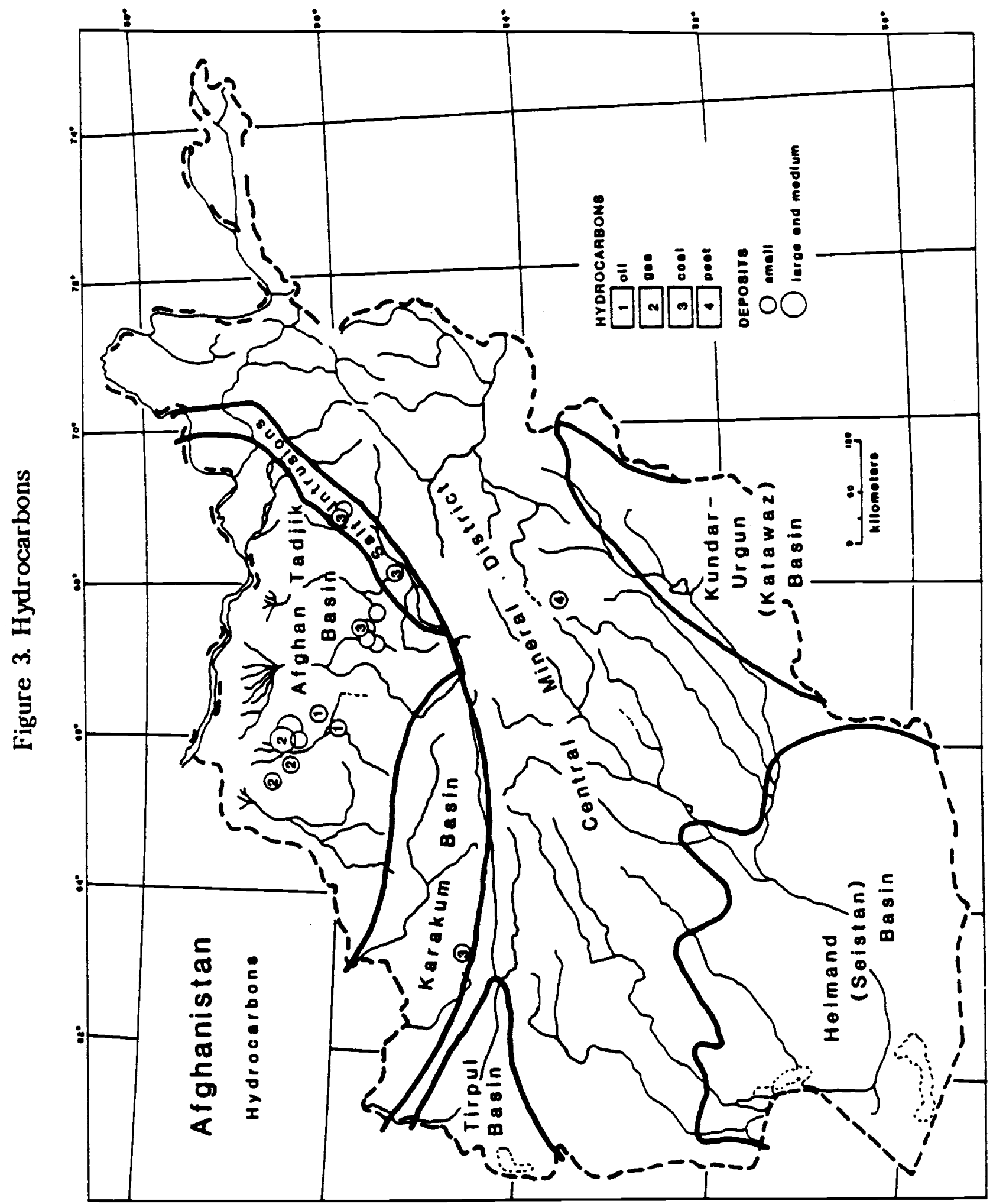


Figure 4 identifies specific zones for ferrous metals, nonferrous metals, industrial minerals, precious stones, and hydrocarbons (e.g., FM1, NF2, IM3, PS4, H5).

These designations for specific zones are used in the tables subsequently presented in Table 1.

Table 1 identifies known metal, mineral, and hydrocarbon occurrences in Afghanistan that may be of commercial significance. The "Map ID" in the first column refers to the zone designations shown in Figure 4. The second column provides descriptive information on each deposit. The final column provides latitude and longitude designations to facilitate the incorporation of this information into Geographic Information Systems (GIS) for Afghanistan.

The following sections discuss the ore deposits believed to be of sufficient size to support smelting operations and the major known hydrocarbon deposits petroleum, natural gas, and coal. Hydroelectric resources (also a part of the energy subsector) are then described.

\section{Potential Smelting Operations}

Several nonfuel deposits appear to be of sufficient size to support future smelting operations if mining operations themselves prove economic. These include (1) the Ainak copper lode south of Kabul, (2) the Hajigak iron deposit high in the Koh-i-Baba range of the central highlands west of Kabul, (3) beryllium-lithium extraction from the Nuristan localities, (4) gold from Zarkashan south of Ghazni and Samti on the Amu Darya, and (5) continued extraction of barite from Sangilayan north of Herat. Of these deposits, only the copper and iron presently appear to be of major interest.

\section{Ainak Copper}

The original estimates in the 1970s of the grade and tonnage of copper at Ainak were that the deposit had some 4.7 million MT of metal in about 280 million MT of ore. Later drilling proved about 11.5 million MT of copper metal could be recovered. Captured Soviet and Afghan documents indicate that in size, richness, and copper content the deposits appear to be the largest in the world (London Telegraph Sunday Magazine 1989). Dr. Yuri Gankovsky, head of the Near East and Mideast Department of the Institute of Oriental Studies, USSR Academy of Sciences, confirmed this in a private 


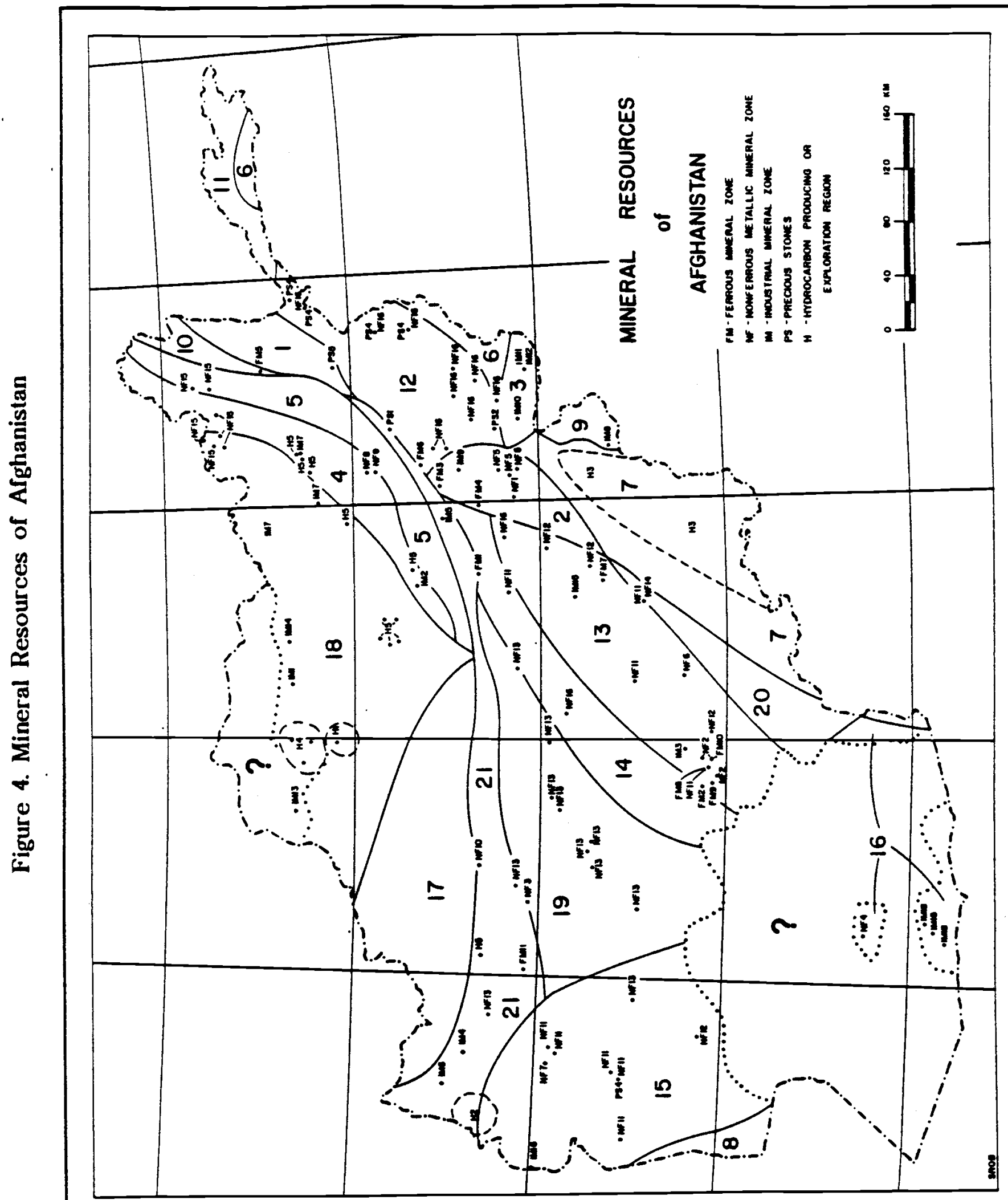




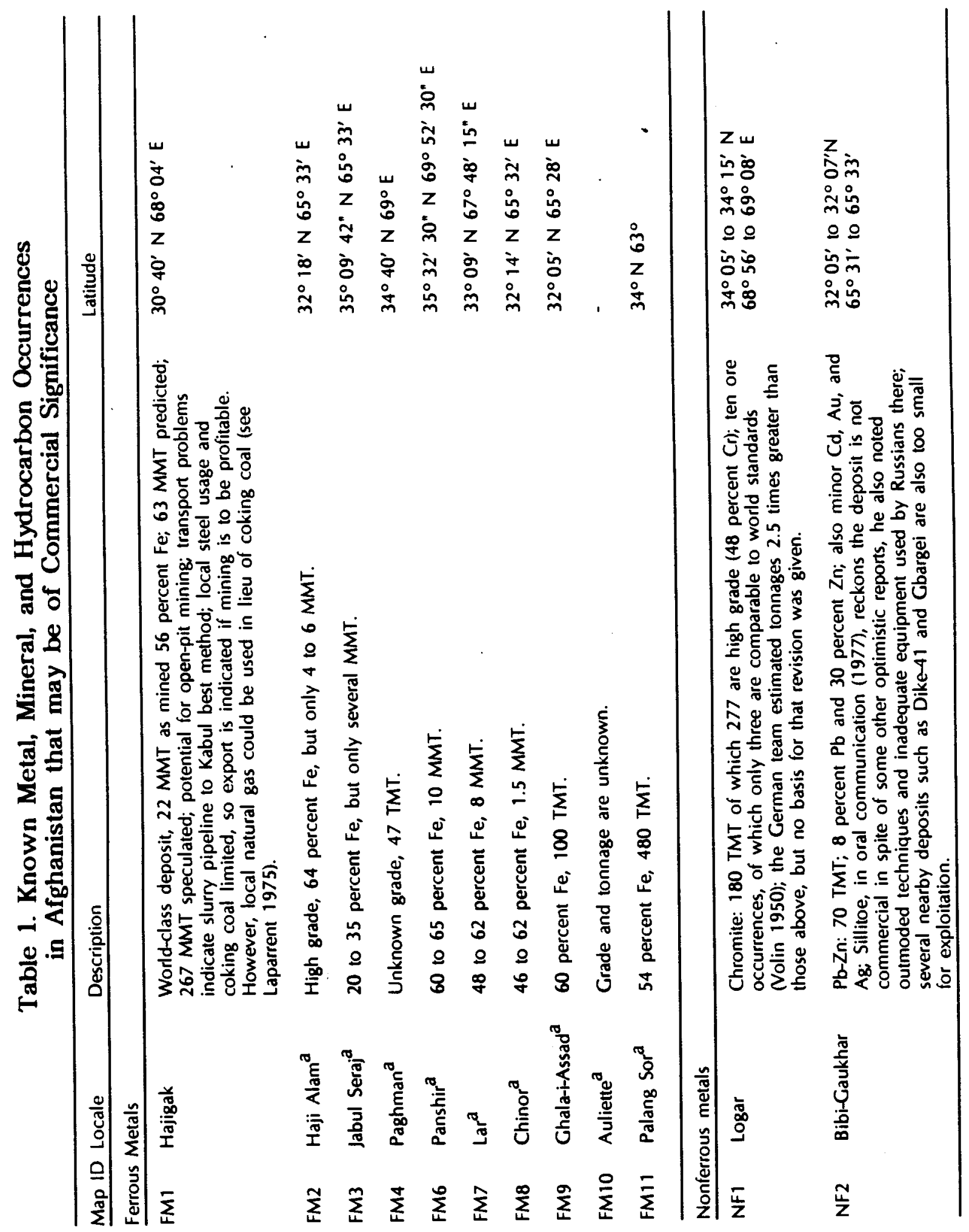




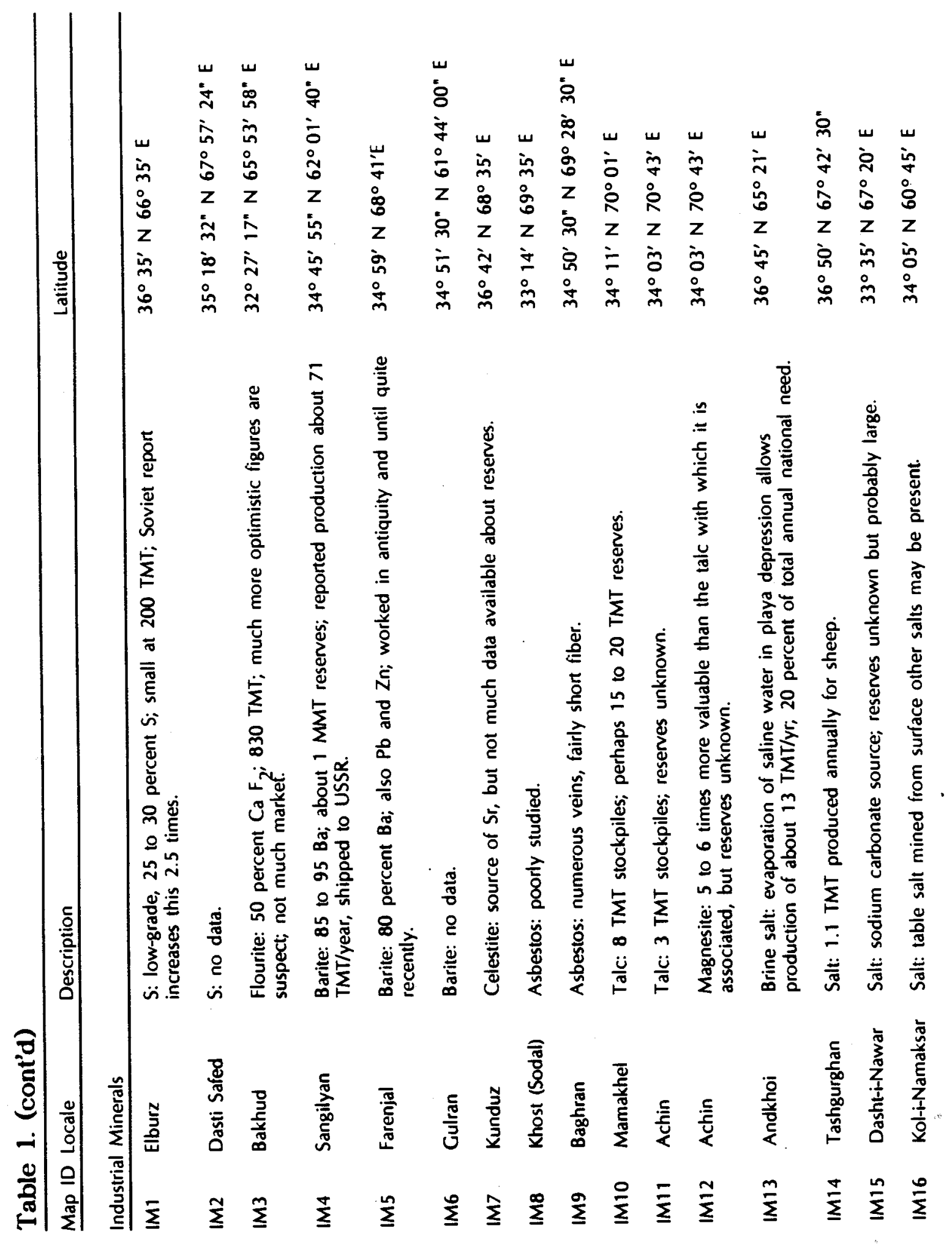




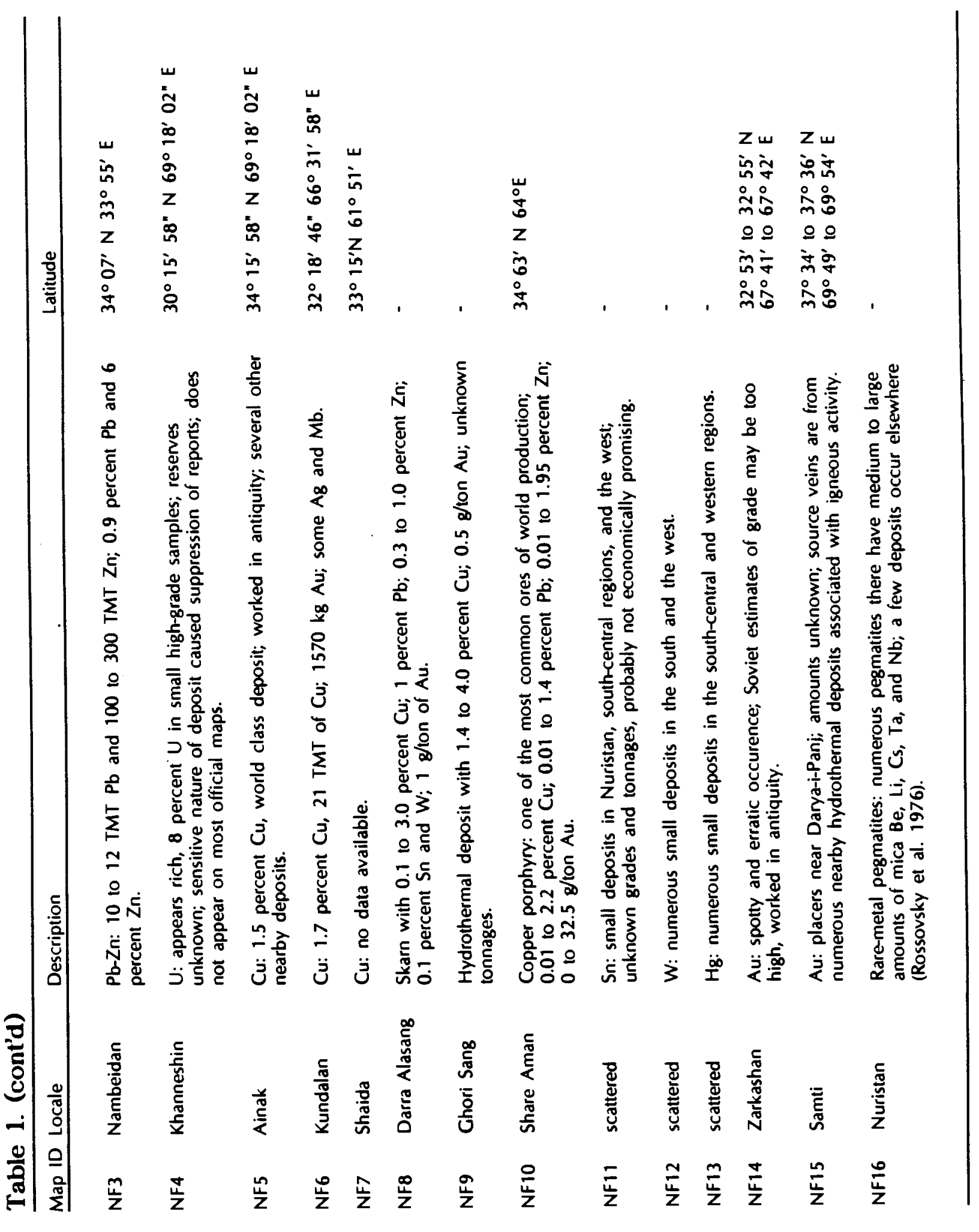




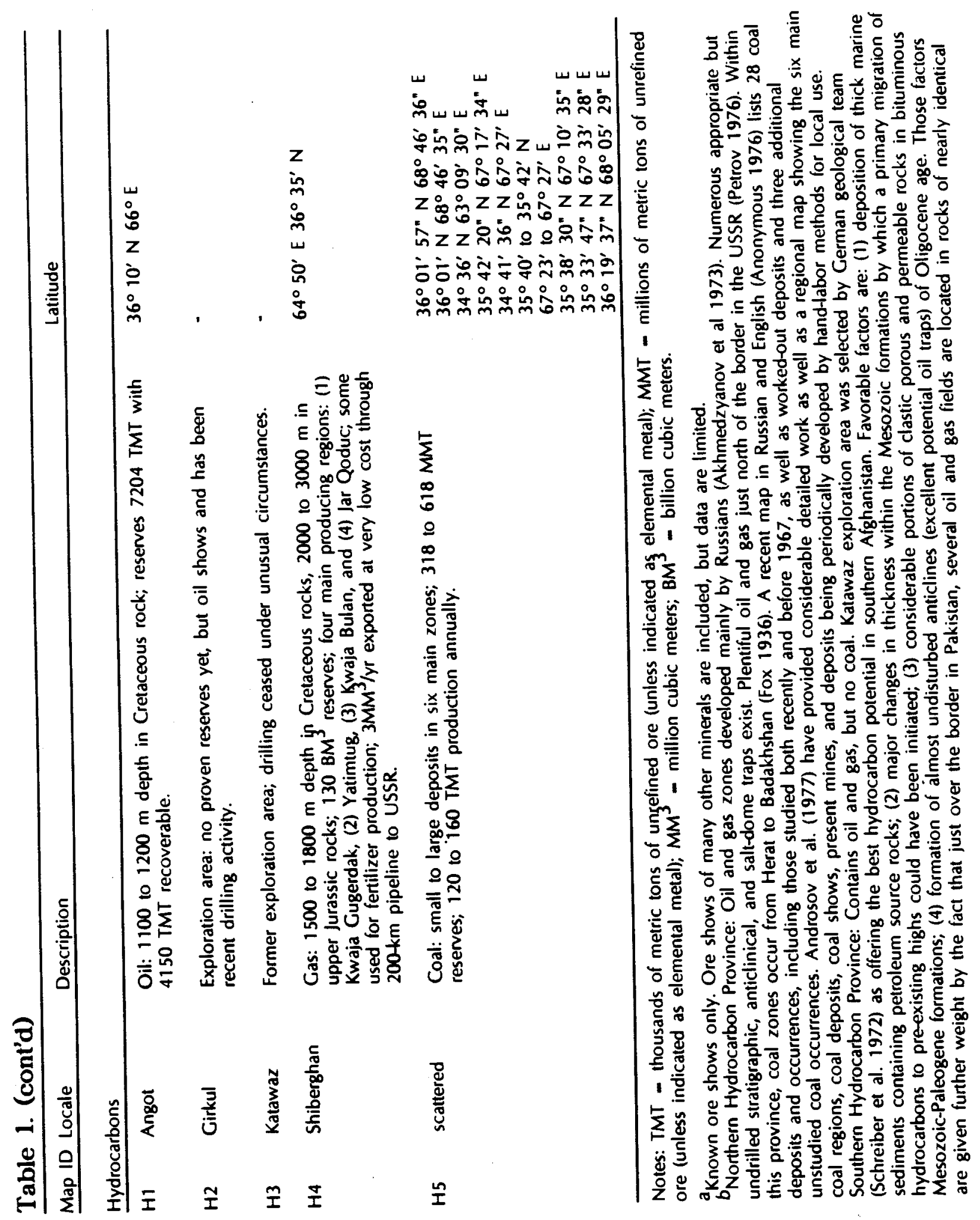




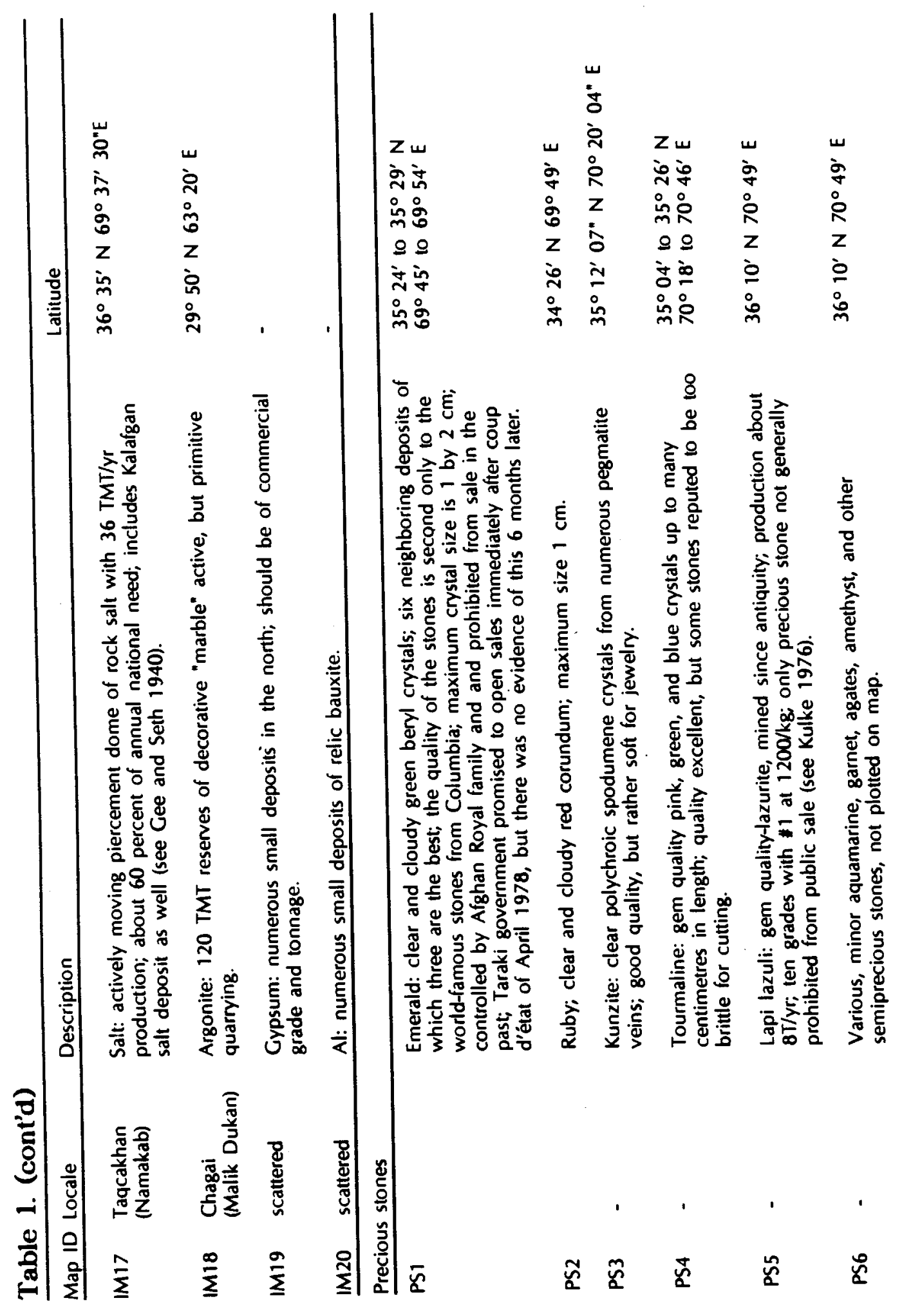




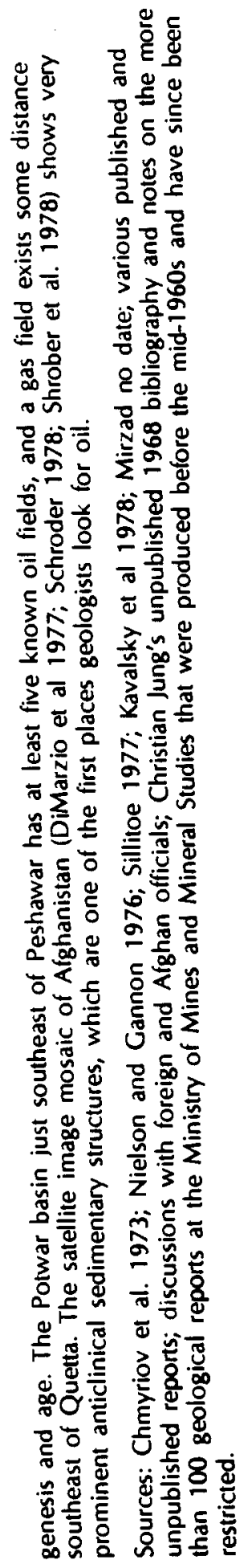


conversation in 1988 with John F. Shroder, Jr. of the University of Nebraska. Journey to Economic Development,the World Bank report issued in 1978, estimated on the basis of the original tonnage estimates that the deposit would capture about 2 percent of the world market. As the world's largest deposit, it may do much better than that if transportation capacity is ensured. The Soviets planned to bring power transmission lines from the north to serve the mine, and to build a 1.5 million MT a year copper smelter as well. The front-ranked Soviet Dzhekkazgan deposits are only one-quarter to onethird as large as those at Ainak and are well past their prime, thus explaining the Soviet interest in Ainak. A first step in bringing Ainak onstream is to gain access to the Soviet's detailed well logs (up to $1 \mathrm{~km} \mathrm{long),}$ ore samples, mine engineering plans, and smelter designs.

\section{Hajigak Iron}

The iron ore deposit at Hajigak is only accessible by steep mountain roads as it lies astride Hajigak Pass in the Koh-i-Baba range. The ore could be transported downhill by conveyor belt or slurry pipeline, but probably not by truck or train because of the expensive return journey. The ore is largely high-grade (67 percent iron), directly shippable, pyrite-magnetite. Measured reserves are about 111 million MT and speculative reserves are a little under 2 billion MT. French geologists judged the deposit to be about the third largest in the world.

Until the communist takeover, international markets showed some interest in Hajigak. A Franco-German company prepared development and exploitation studies, recommending a blast furnace complex about $50 \mathrm{~km}$ north. The French SOFRERAIL project would have brought a rail link near Hajigak, and the Soviets had plans for such a link of their own from the north. But both Soviet and independent UNDP studies showed insufficient local demand to justify iron and steel production for Afghanistan. Moreover, a road-to-rail link could prove very expensive. The Soviets wished to ship raw ore to the USSR; the UN and others saw a possible shipping of ore to the south through Pakistan to the steel mill in Karachi, or perhaps to Japan. Gankovsky pointed out to Shroder that the Pakistanis import iron ore all the way from Australia for their steel mill, and ore from Hajigak might be more economic if suitable transportation links existed. To date, however, no further work has been done here and the deposit remains unmined. A review of the original French and Soviet reports and plans (along with assessment of current demand, supply, and prices) is necessary to decide whether and how to exploit a deposit of this type.

\section{Hydrocarbon Resources}

Five major sedimentary basins with hydrocarbon exploration interest occur in Afghanistan and are shown in Figure 3. The Karakum Basin in the 
northwest contains known reserves, but the Afghan-Tadjik basin to the northeast has several undrilled salt intrusions in likely areas. Both basins have more than 30 large anticlines and other geologic structures of interest. The Tirpul Basin west of Herat is known to contain oil, although the basin is small.

The Karakum Basin and the Afghan Tadjik Basin are at the extreme eastern and southern ends of the great Kopet Dagh hydrocarbon trough that is rich in oil and gas reserves and mostly located in the USSR. Its western extremity is the tremendously rich Baku Peninsula in the Caspian Sea where major Soviet production first started and continues to this day. The large number of potentially favorable anticlines, salt intrusions, and sedimentologic and fault traps known or suspected to be in the Afghanistan portion of the edge of this major hydrocarbon basin indicate that a significant effort should be expended to develop this resource.

The Helmand Basin in the southwest is largely unexplored because of a thick cover of nonpetroliferous sediments, but in 1976 British Tri-Central contracted for exploration in the adjoining western province of Farah. The American Cities Service showed interest in the Dasht-i-Margo and Registan areas of the Helmand Basin; negotiations had reached the contract stage when the 1978 coup occurred, putting an end to these efforts. The Kundar-Urgun (Katawaz) Basin in the southeast was judged to be a likely hydrocarbon zone, and the French company TOTAL began initial exploration in 1974-1975 but decided to pay a substantial penalty rather than continue exploration. TOTAL's formal explanation for its withdrawal was that the geological structures in the area were not of sufficient quality to merit further exploration and that prospects were much better elsewhere for the use of the company's limited resources. There has been some speculation that difficulties in dealing with the Government of Afghanistan or pressures exerted by the Soviets, or both, may have played a role in the company's decision to withdraw. The Afghans themselves continued to work for a time in this area.

Reliable information on reserves and production of Afghanistan's hydrocarbon resources in the north of Afghanistan have been hard to obtain because of tight control by Soviet technicians who have retained much of the documentary data and who have had sole access to the gas meters located in the USSR.

\section{Petroleum}

Oil "gushers" have been drilled at the Angot field in northern Afghanistan. Crude oil production of a few thousand MT a year from the north has been reported. Production rose slowly but steadily by about 20 percent a year through the 1970s. Presumably the crude has been trucked to the USSR. In 1977, proven oil reserves were reported to be only about 10 to 
15 million MT-a mere 5 percent of Brunei or Dubai-and in 1978 reports indicated further unfruitful searches.

Such information on proven reserves suggests that decisions on establishing a refinery in Afghanistan should await the outcome of further explorations. Nevertheless, in 1979 plans were announced to initiate construction of three oil fields and a 500,000-MT refinery. Subsequently, a report prepared for the U.S. Geological Survey in 1990 (Kingston 1990) concluded that Afghanistan's oil reserves are about 80 million barrels and that undiscovered reserves may be on the order of some 300 million barrels. Using the American Petroleum Institute general conversion factor for foreign crude per MT (6.998 barrels to the MT), the estimates in the USGS report translate into 11.4 million MT of known reserves and 42.9 million MT of undiscovered reserves. The figures presented in the 1990 report thus provide a much more favorable picture of the prospects for refinery feasibility than those available before the Soviet invasion.

During their occupation of Afghanistan, the Soviets built two pipelines from the USSR to supply the petroleum needs of their military forces and their Afghan government client. Afghanistan continues to be dependent on foreign supplies of oil-mostly gasoline, diesel, and kerosene-coming from Iran and the USSR. This dependence on foreign supplies has long cost Afghanistan considerable foreign currency resources.

\section{Natural Gas}

In 1963, natural gas was discovered at Khwaja Gugirak, near Sheberghan in Jowzjan province in northern Afghanistan-an area that has subsequently revealed several large natural gas fields with 1977 reserves in excess of 120 billion $\mathrm{m}^{3}$. Production began in 1967. Much of the gas produced ( 80 percent) has been piped to the USSR, with only a small amount (20 percent) going to a $36,000 \mathrm{~kW}$ thermal power plant and a 100,000-MT per year fertilizer plant in Mazar-e-Sharif. In 1979, a team of 200 Soviet geologists explored the north in a continued search for gas. Shortly thereafter, discovery was announced of another gas-bearing zone capable of producing one quarter million $\mathrm{m}^{3}$ per day. Starting in 1976, a heavy investment was made in a gas refining facility to remove sulphur from natural gas (the Jardak Desulphurization Project), and the facility was placed in operation in 1978. Reports since 1979 indicate that as much as 3.5 billion $\mathrm{m}^{3}$ of natural gas were shipped to the USSR in a single year.

In 1984, two new gas fields were found. Work on a second gas pipeline to the Soviet Union was undertaken in the mid-1980s (Nyrop and Seekins 1986). Resistance activities reportedly terminated natural gas shipments to the Soviet Union following the Soviet military withdrawal, but an interview with the Minister of Mines and Industries reported in the Kabul Times in May 1991 
anticipated the resumption of natural gas exports (Resumption of Gas Export 1991).

A 1990 report prepared for the USGS set Afghanistan's discovered reserves of natural gas at 4.64 trillion $\mathrm{ft}^{3}\left(131.5\right.$ billion $\left.\mathrm{m}^{3}\right)$. It estimated the country had some 9.5 trillion $\mathrm{ft}^{3}\left(269.2\right.$ billion $\left.\mathrm{m}^{3}\right)$ of undiscovered natural gas (Resumption of Gas Export 1991).

Importation of natural gas into the USSR may seem paradoxical for a country that possesses the largest gas reserves in the world, about 40 percent of the world supply. However, imports from Afghanistan have been desirable because of the low price set by the Soviets, because they have controlled production, delivery, and gauging; and because the Afghanistan gas serves the southern part of the Central Asian region, the most difficult area for the Soviets to supply from their own trunkline system.

The Soviets built a pipeline through the Salang Pass from the north to Kabul in order to supply truck and tank fuel needs. It is in small diameter, on the surface for much of its path, and for liquids only. It may be advisable in the future to construct a larger diameter, buried pipeline along the same route to service Kabul with natural gas from the north. Such a pipeline had been planned before the war.

In the future, A.I.D. may wish to encourage Afghanistan to arrange for the entry of one or more major oil companies using modern exploration and drilling techniques. Soviet technology in hydrocarbon exploration is known to be inadequate and wasteful in production, and should therefore be avoided in the future.

\section{Coal}

Journey to Economic Development (World Bank, 1978) judged the coal deposits of Afghanistan to be greatly underexploited. About 100 million MT occur in high-grade proven reserves, and another 400 million MT in the probable category. The coal occurs from Herat to Badakshan across the northern part of Afghanistan in nine major deposits, along with 36 other coal occurrences.

Coal mining started at the Karkar and Ishpushta coal mines in the mid1950s. These are close to the cement factory at Ghori and the textile factory at Pul-e-Khumri, which are probably their main customers today to the extent that they are operational. These first coal mines were expected to be exhausted in the early 1980s.

The Darra-i-Suf mine in the Mazar-e-Sharif region is estimated to have a high-quality deposit in excess of 60 million MT of coal. The quality, unlike 
that of the smaller mines, is adequate for iron smelting, and production may have been considerably expanded.

In 1954, about $17,000 \mathrm{MT}$ of coal were produced, increasing in 1965 to about $80,000 \mathrm{MT}$, and in 1979 to about 190,000 MT. Since then production has fluctuated widely because of management problems, an adverse manpower situation caused by an abysmally low pay scale for arduous and unpleasant work, and since 1979, the Soviet invasion and later civil war. The coal has been used in cement plants, textile mills, a cotton mill, a sugar refinery, and the Government of Afghanistan bakery in Kabul. Briquettes of compressed fragments are used for domestic purposes when and where available.

\section{- Hydroelectric Power}

Geographer Hamidullah Amin, in his book A Geography of Afghanistan, (1976) argued that Afghanistan's future industrial development would be based on the development of the country's hydropower potential. The mountainous nature of so much of Afghanistan and the sustained flow of rivers from snowmelt make it possible to construct many falls or cascades at short distances for generation of electric power. The construction of hydropower plants-in contrast to the diesel plants that are in common usage now in the urban areas-requires more investment at the beginning; but their operation is relatively cheap and simple, and they have a longer operational life. In addition, Afghanistan's rivers have generally low sediment loads, unlike the major debris-choked ice streams of much of the Himalayas in neighboring Pakistan. As a result, hydroelectric dams and reservoirs in Afghanistan can be expected to have longer lifespans, other things being equal, than equivalent-sized systems in Pakistan.

According to reports by the United Nations and other published data, as of 1975 only about 8.7 percent of the estimated hydropower potential of the country had been developed. A table of the estimated hydropower potential in $\mathrm{kW}$ follows. The estimate for the Amu Darya is believed to be conservative. Some estimates place the hydroelectric potential of the entire Amu Darya river system at more than 10 million megawatts.

$\begin{array}{lr}\text { Watershed } & \begin{array}{c}\text { Estimated } \\ \text { Potential } \\ (\mathrm{kW})\end{array} \\ \text { Amu Darya } & 2,500,000 \\ \text { Hari Rud } & 150,000 \\ \text { Helmand } & 700,000 \\ \text { Kabul } & 750,000 \\ \text { Kokcha } & 300,000 \\ \text { Kunduz } & 500,000 \\ \text { Miscellaneous } & 100,000 \\ \quad \text { Total } & 5,000,000\end{array}$


The first hydroelectric station south of the Hindu Kush was started in 1921-1922 in Jabul Seraj north of Kabul with two turbines whose capacity was $1,500 \mathrm{~kW}$ hours. The electricity was partly used for the textile factory there and partly sent to Kabul. In the mid-1970s, its electricity was transmitted only to Charikar and its present disposition is now unknown. Between 1936 and 1941, the Siemens company of Germany built two hydroelectric dams; one in Wardak and one in Pul-i-Khumri. The 1941 Wardak installation had three generators with a total capacity of $3,360 \mathrm{~kW}$ hours, using water at $17 \mathrm{~m}^{3} / \mathrm{second}$. Its present condition is unknown. The Sarobi dam on the road between Kabul and Jalalabad was started by the Germans in 1951 and finished in 1958. Two turbines produced 22,000 kW hours. Below this site, in the gorge between Sarobi and Laghman, it would be possible to add three or four more such stations.

The Sarobi station was badly damaged in the recent war and may now not be functional. Construction of the Naglo station in this region was undertaken in 1960 and completed in 1968, with a storage dam capacity of 530 million $\mathrm{m}^{3}$ of water that safeguarded and regulated the flow of water for Sarobi and Darunta. The three turbines of Naglo were producing $76,000 \mathrm{~kW}$ hours, and the addition of a fourth in the 1970s increased capacity to 97,000 $\mathrm{kW}$ hours. In 1964, construction began on a dam at Mahipar in this area as well. This plant had three turbines and produced $60,000 \mathrm{~kW}$ hours, but only during winter. The Darunta dam began operating in 1964, mainly to irrigate of the Jalalabad Plains, and produced $11,000 \mathrm{~kW}$ hours as well. This power was used for the city and local industry and for pumping water to the higher elevation irrigation canals.

North of the Hindu Kush the first Pul-i-Khumri plant was installed in 1943 with a capacity of $4,800 \mathrm{~kW}$ hours and a second one in 1962 at $9,900 \mathrm{~kW}$ hours. This electricity was used for industry and lighting in Pul-i-Khumri, Baghlan, and Kunduz. The power plant built at Khanabad in the north had a capacity of $1,400 \mathrm{~kW}$ hours and supplied Kunduz and Khanabad.

In the southwest, a hydroelectric plant was built in 1958 at Girishk on the Helmand with a capacity of $2,400 \mathrm{~kW}$ hours. The massive Kajakai dam on the Helmand was built to control irrigation flow on the Helmand project, as well as to provide $33,000 \mathrm{~kW}$ hours for the Kandahar, Laskargah, and Girishk areas.

The total production of electricity in Afghanistan, which was 47.1 million $\mathrm{kW}$ hours in 1957-1958, increased to 395 million kW hours in 1970-1971, and 527.2 million $\mathrm{kW}$ hours in 1974-1975. Electricity generating capacity is 410 MW-254 from hydroelectric sources, 48 from gas, 60 from diesel, and 48 from a thermal power plant. During the Soviet occupation numerous power pylons and power plants were destroyed, mostly by the Afghan resistance to deny electricity to the Soviet invaders and their client regimes. The present state of power production inside Afghanistan must, therefore, be lower than it was in the late 1970s, but exactly how much lower is unknown. The 
transmission line between the Kajakai hydroelectric plant and Kandahar was destroyed early in the war, so its 33 Megawatts have been unused for some 10 years. On the other hand, the Kabul government bought 140 diesel generators for its garrison towns and built lines from the Soviet power net to Mazar-e-Sharif and Kunduz. Official figures show electricity imports from the USSR rising from 15 million $\mathrm{kW}$ hours in 1986-1987 to 37 million $\mathrm{kW}$ hours in 1987-1988. The cost of these imports has so far been covered by Soviet commodity aid.

Furthermore, although the development and expansion of power production capacity during the 1960 s and 1970s was considerable, it nevertheless did not meet the requirements of the country, and the amount of power produced per capita remained very low. Power production per person in 1971-1972 was about $25 \mathrm{~kW}$ hours, and increased to only about 28 $\mathrm{kW}$ hours by 1974-1975. Only 5 percent of the people have access to electricity, and 80 percent of the supply is consumed in Kabul. Power supply is quite low compared with most other countries, and thus in the prewar situation the construction of new power plants, reduction of power losses, and expansion of the distribution system were considered to be of paramount interest. In addition, power losses through faulty design and theft tended to be enormous such that in 1970-1971, 39 percent of the total power generated was lost.

In any post-war redevelopment plan, the reconstruction of the original system will be of major importance. Given the haphazard engineering and maintenance of much of the prior work, original documents, plans, blueprints, spare parts, and other support materials may well have been lost. An early nationwide survey of immediate energy needs should be arranged so that available resources can be used and expanded for the most important purposes. A phased energy reconstruction and development plan should be formulated for all of the major energy sources, as well as wood fuels and solar energy, and should include cross-border exports and imports.

\section{Recent Maps, Inventories, and Studies of Afghanistan's Mineral Resources}

The systematic study of the geology and metallogeny of the country was not begun in Afghanistan until the 1950s. The Afghan Geological Survey was founded late in that decade. As noted in Chapter 2, in the 1960s a U.S. team prepared high-quality, large-scale topographic maps of the southern two-thirds of Afghanistan that could be used to map geological features and plan development projects. The Soviets prepared maps for the northern third, but the overlap between the resulting two sets of maps was not fully compatible, even though ground surveys and control points were used carefully. 
Pertinent Publications, 1972-1973

Five important maps were printed in Kabul in 1972. The publication of the maps was followed in 1973 by articles that described and explained four of these maps. The five maps were as follows:

- Geologic Map (1:1,000,000);

- Mineral Resources Map (1:1,000,000);

- Tectonic Map (1:1,000,000);

- Magmatic Complexes Map (1:1,000,000); and

- Geologic Map of Central and Southwestern Afghanistan (1:500,000).

The Geologic Map of Central and Southwestern Afghanistan was prepared by the German Geological Mission to Afghanistan (Weippert, Wittekind) mainly on the basis of aerial photo interpretation and some field work.

In 1973, the Department of Geological Survey in the Ministry of Mines and Industries of the Government of Afghanistan, published Geology and Mineral Resources of Afghanistan, a 110-page book containing articles that described and explained the first four maps. The first paper in the book, "The Main Features of the Tectonics of Afghanistan," was written by Sborshchikov et al. It defined the regional geologic structure of Afghanistan. The second paper by Stazhilo-Alekseev et al. entitled "The Main Features of Magmatism of Afghanistan," defines the main cycles of igneous activity and the associated mineralization. Chymriov et al. discussed, "The Mineral Resources of Afghanistan."

A paper by Dronov et al. on "Scheme of Stratigraphy of Afghanistan" and a paper by Akhmedzyanov et al. on "Petroleum and Gas Prospects of Sangcharak Basin" were also in this book. "Petroleum and Gas Prospects of Sangcharak Basin" had several pages of history of drilling, structure, and general stratigraphy and a few short comments on oil and gas. The paucity of detailed information on oil and gas is noteworthy.

Geology and Mineral Resources of Afghanistan was published in English. It was translated, presumably from the original Russian language. The publication was replete with mistranslations and opaque English and contained limited information, especially on the most important mineral deposits. Many of the citations were unreferenced in the bibliography. 
A 68-page document, entitled the Eighth Supplement Chapter On: Industries and Mines (Report No. 490 in the A.I.D. Library in Kabul), that had become available from the Ministry of Planning in 1972 was in fact more specific about oil, gas, iron, and industry than the four papers published in 1973. This 1972 report did not mention the Ainak copper deposit, however. The document reported on elements of the Five-Year Plan process and was in readable English. It contained an accounting of past and projected expenditures in certain development areas as well. Pertinent subjects that it covered included exploration for petroleum and gas, prospects for a petroleum refinery, chemical fertilizer and thermal power factories, an asbestos products manufacturing plant; iron smelting factory, gas industries, exploration of solid minerals, and electric energy.

Pertinent Publications, 1974-1977

In 1974, the Geological Survey of Afghanistan, with technical assistance from the USSR, completed work on the geological and mineralogical survey of Afghanistan, at a scale of 1:500,000. In 1976, the following maps were compiled:

- Geological Map (1:500,000);

- Mineral Resources Map (1:500,000; 1:200,000);

- Revised Tectonic Map (1:2,500,000);

- Metallogenic Zoning Map (1:5,000,000);

- Hydrogeological Map (1:2,000,000); and

- Magmatic Complex Map (1:2,000,000).

A 1977 Government of Afghanistan Study, Mineral Resources of Afghanistan 2nd ed., was four times larger than the 1973 version and consisted of 419 pages and a dozen folded maps. Sixty percent of its 164 references had been published in the 5-year period 1972-1976, and all but 9 percent had been published in 1964 or subsequently.

The 1977 report represents an abridged version of previous work, and includes data on the geological surveys and mineralogical investigations carried out since 1963 by Soviet and Afghan geological teams, with an emphasis on the future economic potential of Afghanistan. The authors listed are Shareq, Chmyriov, Stazhilo-Alekseev, Dronov, Gannon, Lubemov, Kafarskiy, and Malyarov. The original manuscript was translated from the Russian into English by G. M. Bezulov (not an author of any of the references used in the report), and was edited by Patrick J. Gannon, consulting mining geologist from Toronto, Canada, who was working for the United Nations Development 
Programme (UNDP). The document is in quite good English and seems scientifically sound, unlike the earlier version of 1973 . The work was financed by UNDP and the Canadian government.

The 1977 report begins with a discussion of the main geologic features of Afghanistan, including stratigraphy, igneous rocks, and tectonics. On this basis, the metallogenic features of the country are then discussed. With this as a framework, more than 1,400 specific mineral resource locations are described and classified into three categories: (1) deposits, (2) occurrences, and (3) showings. In addition, more than 300 broadly defined mechanical mineralogical haloes are discussed because they suggest potential occurrences of specific minerals. This catalogue of mineral localities occupies the bulk of the report-290 pages or 70 percent of it. An important concluding section deals with groundwater resources, defining the aquifers and describing specific localities-which include 86 freshwater wells and springs, mainly in the desert.

Excellent maps are included in the report "Graph Annexes", as follows:

- Geologic Map (1:2,500,000).

- Tectonic Map (1:2,500,000).

- Magmatic Complexes Map (1:2,000,000).

- Metallogenetic Zones Map (1:5,00,000).

- Mineral Deposits and Occurrences Maps (1:2,00,000):

- Fuel Minerals and Ferrous Metals

- Nonferrous Metals

- Tungsten and Tin

- Rare and Precious Metals

- Nonmetallic Minerals

In 1980, Dr. Allen Agnew, Senior Specialist in Environmental Policy for the Congressional Research Service of the Library of Congress and now Professor Emeritus of the Department of Earth Sciences of Oregon State University, commented on the 1977 document in a letter to a U.S. government official as follows: 
For a country that has been said by some to be relatively poor in natural resources, Afghanistan is now shown to contain more than merely "promising" mineral potential. The 1977 report presents a wealth of information on specific mineral localities, and the map of mining districts... shows their location within the metallogenic framework of the country. (Agnew, 1980)

Some Western European and U.S. geologists have disagreed with Soviet geologists on the details of how they arrive at their metallogenic classification. The Western geologists believe that the Soviet geologists who prepared the 1977 report were more optimistic about the value of the mineral deposits than geologists who have derived their experience from market economies. However, even if USSR geologists were overly enthusiastic about the economics of individual deposits, future transportation improvements undertaken with a larger view of sectoral or national development potentials in mind could provide more attractive cost structures for individual investments in mineral exploitation.

\section{Recent Publications}

With a few exceptions, Resistance activities in the countryside severely limited mineral exploration and exploitation activity after the 1978 communist coup. Reports of Resistance mining of gemstones have appeared in the press from time to time (see, for example Simpson 1990 and In Business Again 1990). Most of the map and survey materials published since then are derived from data gathered in earlier years. In 1981, H. Afzali, the former Director of the Afghan Geological Survey, published a 22-page overview of Afghanistan's hydrocarbon, metal, and industrial mineral resources in a French journal, Chronique de la recherche miniere (Afzali 1981). In the following year, Mr. Afzali presented a geological and mining bibliography in the same journal (Afzali 1982).

In 1985, a National Atlas for the Democratic Republic of Afghanistan was published by GEOKART (Organization for Surveying and Cartography) in Poland. The Atlas contains some 51 maps including geology, tectonics, geomorphology, mineral resources, and hydrography. All of these maps are on the scale of $1: 6,000,000$. A list of pertinent source maps for the 1985 National Atlas of Afghanistan follows.

Geological Map of Afghanistan, 1:2,000,000, Kafarskiy, A. Kh. et al., Ministry of Mines and Industries, Kabul, 1975.

Geomorphological Map of Afghanistan, 1:1,000,000, Halikov, C. H. et al., Ministry of Water and Power, Kabul 1979 (original).

Hydrogeological Map of Afghanistan, 1:2,000,000, Malyarov, E. P. et al., Ministry of Mines and Industries, Kabul 1976. 
Map of Mineral Deposits and Occurrences of Ferrous Metals and Fuel Minerals of Afghanistan, 1:2,000,000, Chmyrlov, V.M. et al., Ministry of Mines and Industries, Kabul 1976.

Map of Mineral Deposits and Occurrences of Nonferrous Metals of Afghanistan, 1:2,000,000, Chmyrlov, V.M. et al., Ministry of Mines and Industries, Kabul 1976.

Map of Mineral Deposits and Occurrences of Nonmetallic Minerals of Afghanistan, 1:2,000,000 Chmyrlov, V.M. et al., Ministry of Mines and Industries, Kabul 1976.

Map of Mineral Deposits and Occurrences of Rare and Precious Metals of Afghanistan, 1:2,000,000, Chmyrlov, V.M. et al., Ministry of Mines and Industries, Kabul 1976.

Map of Mineral Deposits and Occurrences of Tin, Tungsten, Molybdenium and Bismuth of Afghanistan, 1:2,000,000, Chmyrlov, V.M. et al, Ministry of Mines and Industries, Kabul 1976.

Map of Mines, 1:2,000,000, Afghan Cartographic and Cadastral Survey's Institute/Ministry of Mines and Industries, Kabul 1979 (original).

Tectonic Map of Afghanistan, 1:2,000,000, Kafarskiy, A. Kh. et al., Ministry of Mines and Industries, Kabul 1975.

Of the 10 maps shown in the exhibit, only two (Geomorphological Map of Afghanistan and Map of Mines) bear 1979 dates and could well be based on data gathered in earlier years.

In 1985 Guy Mennessier and Noel Beun published five geologic maps of areas between Gol-Bahar and Ab-e-Istada. These maps varied in scale from $1: 50,000$ to $1: 250,000$ and bore dates ranging from 1972 to 1984 . In the same year, Dorothy B. Vitiallano translated from the Russian a substantial portion of a 1970 report entitled Geology and Oil and Gas Potential of Northern Afghanistan. In 1990, John Kingston prepared a report for the U.S. Geological Survey on oil and gas potentials of Afghanistan referred to in prior sections of this chapter.

\section{Gaining Access to Information from Soviet Bloc Sources}

Recent developments in the former Soviet bloc countries promise easier access to information obtained by Soviet geologists in Afghanistan in the past. Circumstances effecting access to geological information are somewhat different for each Eastern bloc country. The East German geological organization has been absorbed by the former West German 
geological establishment. Several other Eastern European nations that have rejected communism, including Czechoslovakia, Poland, and Hungary, are receiving assistance from the U.S. Geological Survey (USGS). Bulgaria, Uzbekistan, Azerbaijan, and the Russian Federation have shown interest in receiving assistance from USGS. USGS hopes to mount a Mission to the Confederation of Independent States (CIS) to survey the needs of CIS governments and of newly formed and reformed minerals organizations that are now urgently arranging to earn foreign exchange through minerals exports.

\section{Background}

The expansion of access to information in the Soviet Union during the Gorbachev era, changes occurring within the former Soviet republics, and collaboration between CIS states and Western minerals companies raise hopes that previously restricted data on the minerals sector in Afghanistan can be obtained from CIS sources as well as from other former Soviet bloc nations.

Gorbachev came to power in 1985 and introduced a policy of Glasnost (openness). That policy took hold in varying degrees within the Soviet government in subsequent years. The Geneva Accords on Afghanistan were reached in early 1988 and Soviet troops were officially withdrawn in 1989. Except, perhaps, for the mining of strategic materials (reportedly carried out by Soviet technicians protected by Soviet troops, without the presence of Afghan counterparts), active attempts to locate and exploit minerals in Afghanistan ceased in the early years of the Soviet intervention. Resistance control of most areas outside the cities; the capture, in the countryside, and execution of the Soviet leader of a minerals exploration team by a mujahidiin commander; and the kidnapping from the streets of Kabul of the head of the Soviet minerals advisory team in the country probably contributed to the reduction in activity. Resistance forces succeeded in interrupting the flow of natural gas to the Soviet Union and in frustrating efforts of the Kabul government and the Soviets to exploit copper deposits at Ainak.

The Soviets understated or attempted to hide a number of important findings concerning Afghanistan's minerals potentials from the Afghan government, but the Afghan government was often not convinced. Afghans have a long-standing tradition of skepticism toward the reports and motivation of foreign experts involved in minerals exploration in the country (see Gregorian 1969 and Fox 1943). ${ }^{7}$ Toward the end of President Daoud's rule, this skepticism came to dominate thinking concerning Soviet intentions in developing Afghanistan's minerals and many other Soviet activities. By the time of the communist coup, the government was aware that the Ainak

${ }^{7}$ Fox was an American geologist who sought out mineral deposits in Afghanistan for an American exploration company before World War II. 
reserves and other important deposits was likely to have been underestimated by the Soviets.

Because of Soviet procrastination in funding the construction of an oil refinery project considered very important by the Afghan government, Daoud authorized his Minister of Mines and Industries to carry out independent drilling tests for petroleum. In response to Soviet arguments that Afghanistan lacked oil reserves of sufficient quantity and quality to support a refinery, the Minister confronted the Soviet Ambassador with high quality samples obtained from test oil drillings conducted in promising areas in the north of the country. As Daoud sought to reduce Soviet influence on his government, he authorized the use of the United Nations Development Programme (UNDP) as an alternative source of assistance in exploration for minerals, such as uranium explorations that the Soviet Ambassador had offered to undertake with grant funds in 1977.

In the mid-1970's, the Government of Afghanistan accepted a Soviet offer to refly portions of a West German aerial survey for which no data had been provided to the Afghan government by the West Germans. However, no results were reported to the Afghan government when the Soviet flights were completed. The Ministry of Mines and Industries inferred from information from airport observers that the Soviet aerial surveyors had encountered heavy radiation. The ministry eventually sent its own geologists to the area (in the Khan Nishien Mountains), obtained and analyzed samples, and discovered that these samples contained rich uranium ore.

Once the Soviet aerial surveys were completed, the Soviet Ambassador repeatedly requested permission to explore the Khan Nishien Mountains, offering grant funds for the purpose. He was told that the Afghan government and the UNDP had established an agreement for UNDP explorations. Ministry officials surmised that West Germans had discovered the radiation in earlier flights and reported it to their own government without informing the Afghan government, and that Soviet intelligence had discovered this information by infiltrating the Government of West Germany. Shortly after invading Afghanistan, the Soviets reportedly sent a military force to the area and commenced uranium mining operations under heavy guard.

\section{Approach to Obtaining Information}

In order to formulate an approach to obtaining information that may be available in the former Eastern bloc nations, the study team examined the pertinent literature published both before and after the Soviet invasion. By far, the largest number of Eastern bloc geologists were from the Soviet Union and were heavily involved in the minerals sector, and a few were from Czechoslovakia and were primarily involved in coal and cement. No solid evidence of East German involvement was found but the possibility was pursued. The head of the International Division of the German Geological 
Survey was contacted. He arranged for a direct communication from the Survey's (former East German) unit in Berlin. The response from the Berlin office was that they had "no data of recent date" available in their archives.

.In response to the study team's enquiry, the Czech Geological Survey provided citations for 12 articles, of which 8 were written between 1959 and 1968 and 4 were written between 1981 and 1983. They also provided the names and addresses of three persons (submitted to O/AID/Rep separately) with experience in Afghanistan in the early 1980s and with the address and telephone number of the Mining Projects Institute in Ostrava. The Czech Geological Survey appears to be enthusiastic about future collaboration in studies and other activities, particularly if appropriate funding is available.

In contrast to the Czech geologists, whose minerals-related activities in Afghanistan and production of professional papers appear to be quite limited, Soviet geologists publishing on Afghanistan number in the hundreds. Available references to the literature were screened, primarily for (1) publications ostensibly dealing with economic feasibility of particular minerals projects and (2) publications that might provide new insights into potential of minerals development projects considered especially important for Afghanistan. The selected annotated bibliography in the appendix to this report contains those relatively few items that most closely pertain to these two concerns.

One of the study team's translators visited the Soviet Union in the summer of 1991 on a different assignment. In the course of his research, he found that formerly classified geological studies have been declassified and that the atmosphere of greater openness did indeed prevail. However, the libraries and research institutions are operating very slowly by U.S. standards and many geologists employed by the government face compensation and job security problems. His opinion was that both institutions and individuals with background in Afghanistan's minerals sector would be eager to take part in compensated professional endeavors, but that locating appropriate persons and data is likely to be time-consuming.

A less encouraging opinion has been expressed by the Chief of Exploration of a major German metals company (Metallgesellschaft AG). At a conference held in Washington in late January, 1992 he reported that, "the former Soviet Union still keeps its nonferrous metal production statistics secret, as they were seen as strategic and formed part of the militaryindustrial complex."

It is generally agreed, however, that in the closing Gorbachev years in the USSR and the early months of Yeltsin's leadership in the now independent Russia, there have been a series of rapid changes in the institutional structure of the minerals sector and the policies applied to it.

Before the Gorbachev era, the Soviet Union's umbrella Ministry of Geology, which was responsible for exploration and research (but not mining 
or petroleum extraction), had more than 800,000 employees and exercised strong central control over these functions. Some of the Soviet republics, such as Uzbekistan, had ministries of geology, but such ministries were very much subordinated to the All-Union Ministry. Under Gorbachev, these state ministries of geology were technically downgraded to the status of "committees," but decentralization also started to take hold in the last years of his rule. By mid-1991, local geological institutes and local units of government started making direct contacts with foreign companies, seeking the formation of joint ventures.

With the formation of the CIS, the umbrella Ministry of Geology of the USSR was dissolved. Russia, Ukraine, and the central Asian states are believed to have absorbed significant portions of its staff. In theory, at least, the importance of the state ministries or committees of individual republics should grow, but there are many uncertainties concerning their roles and funding. It has been reported that as many as 360,000 geologists may currently be unemployed, unpaid, or risk losing their jobs in CIS countries.

Gorbachev's policy at the end of his rule was to open the minerals sector to foreign investment but to confine it to projects that had not been selected for state funding. By contrast, Yeltsin's policy for the Russian Federation has been to encourage local authorities to enter into a wide range of joint ventures with foreign minerals development firms. There is disagreement concerning the respective roles of state-level committees and local authorities and their relationships have not yet been fully defined. In the next few months, considerable leadership energy is expected to be expended in reaching agreements on these matters.

The old USSR comprised 15 republics. Latvia, Lithuania, and Estonia established their independence first, leaving 12 within the Soviet Union. Following the formation of the -CIS, the United States recognized the existence of all 12 as independent states, but thus far has recognized the governments of only 6: Armenia, Belarus, Kazakhstan, Kyrgyzstan, the Russian Federation, and Ukraine. Tajikistan, Turkmenistan, and Uzbekistan (the 3 former Soviet republics along Afghanistan's northern border) are among the 6 states that have not yet been recognized by the United States.

The United States is currently represented only in Russia (Moscow and St. Petersburg) and Ukraine (Kiev). It will probably be some time before U.S. representatives are stationed in the other four countries whose governments are recognized by the United States. The remaining six governments have not yet met U.S. recognition criteria.

A number of possible ways exist to pursue individual contacts and information pertaining to Afghanistan's minerals sector within the CIS. These include, but are by no means limited to 
- Making formal inquiries through the U.S. embassies in Russia and Ukraine. These two newly independent states have taken over significant portions of the staff of the former umbrella Ministry of Geology, and well may have staff members who served in Afghanistan.

- Awaiting the establishment of relationships between individual states and the USGS and then proceeding with the assistance of the USGS. In the case of Czechoslovakia, simply mentioning the names of key USGS officials known to the Czech Ministry of Geology opened doors very quickly. If the timing of USGS involvement with CIS states is correct, such an approach might prove quite effective.

Directly contacting academies and institutes that have participated in research on the minerals sector in Afghanistan (such as the Academy of Sciences and Institute of the Geology of Ore Deposits, Petrography, Mineralogy, and Geochemistry in Moscow) or their successors.

- Directly contacting geological journals (such as Geologiia Nefti $i$ Gaza in Moscow) and publishing organizations (such as the Nedra Press in Moscow) that have published materials on Afghanistan.

- Directly contacting state technical committees or ministries of geology in individual states, particularly those (such as Uzbekistan) that have supplied personnel to or served as sources of studies on Afghanistan.

- Approach U.S. or Western European minerals exploration and exploitation companies with joint venture agreements or other continuing relationships in the CIS who may be willing to provide advice on contacts.

\section{Conclusions}

The views of the study team members and others whose advice was sought may be summarized as follows.

1. Given the atmosphere of turbulence in the new CIS and the continuing changes in the structure of geological organizations, it may take some time and effort to focus the attention of their leadership on matters pertaining to past Soviet work in Afghanistan.

2. Once people and organizations with access (or past access) to the information have been found, a high degree of cooperation may be anticipated if suitable compensation is provided. 
3. In cases where information has been deliberately falsified, ability to locate correct information will probably depend in large part on the level of the organization at which the falsification occurred. Establishing that information is in fact accurate may be considerably more difficult than finding the information in the first place.

4. Techniques of exploration and estimating the contents of deposits have advanced significantly in the past decade. In many cases, methods and equipment used in the West are better than those used in the Eastern bloc.

5. In addition to language barriers, communication problems may arise between Eastern bloc and Western geologists stemming from differences in professional training, practices, and philosophy.

6. Concepts of minerals economics and financial feasibility, in particular, are poorly understood by those who have grown up in the command economies of the Eastern bloc, where it is quite common to mine a deposit long after it would be abandoned in the West and to dispose of tailings from which considerable value would first be extracted if the operation were carried out by commercial mining organizations here.

7. It is not known whether some or all of the countries of the CIS will continue to regard as state secrets information concerning uranium, certain rare earths, and other mineral deposits in Afghanistan that could be used to produce modern weapons systems.

8. Some organizations within the CIS may regard information on commercially exploitable mineral deposits in Afghanistan as having a market value well beyond the reasonable value of the services required to assemble, reproduce, or analyze it (standards usually applied by A.I.D. in obtaining information).

9. The organizational status of geological functions in CIS countries is very much in a state of flux and will probably take some time to crystallize.

10. A new Government of Afghanistan may not give much credence or weight to information provided solely by sources within the former Soviet Union.

An approach that assistance donors should seriously consider is incorporating knowledgeable Soviet specialists into teams of international experts studying particular mineral sector opportunities. Once a firm scope of work and funding are available for a given study, notices concerning types of 
Afghanistan experience and information sought could be placed in Soviet geological publications. Payment could be offered for future service and for particular reports or information thought to have been gathered in Afghanistan by Soviet experts in the past. Another approach is to simply request resumes of those who carried out or were responsible for geological work in Afghanistan. However, such an approach could generate a high volume of resumes, the screening of which would become a major effort.

Gaining access to former Soviet geological technical advisers and organizations and unearthing formerly classified documents in the CIS could provide shortcuts for mineral development activities in Afghanistan. The Soviets may also have left some basic data, such as drilling logs, in Afghanistan or in other locations where they can be retrieved and utilized without the involvement of the geologists who created them. However, for most purposes, interactive contact between geologists from the former Soviet Union and experts from other countries on specifically defined assignments would appear to be the best and most cost-effective method of obtaining accurate information on past Soviet findings and of establishing their accuracy and probity.

\section{Other Sources}

Although there are literally thousands of sources of primary and secondary information on the minerals of Afghanistan, the most pivotal source remains the 1977 work Mineral Resources of Afghanistan. The World Bank's Afghanistan: The Journey to Economic Development (1978) is a good secondary source. John F. Shroder, Jr., Chairman of the Department of Geography and Geology at the University of Nebraska at Omaha is the author and coauthor of a number of informative articles on Afghanistan's mineral resources (see, for example, Schroder and Assifi 1984; Schroder 1981; Schroder 1984; Schroder 1989; and Afghanistan and the Soviet Union: Collision and Transformation, 1989).

The U.S. Geological Survey Library in Reston, Virginia, the Library of Congress, and the Library of the University of Nebraska at Omaha have the best collections of information on Afghanistan's minerals sector in the United States. An extensive photocopied collection of major or primary sources in abstract, summary, or entire article form is available at the Nathan/Berger office in Arlington, Virginia, and through Dr. John F. Shroder, Jr. at the University of Nebraska at Omaha.

Dr. Shroder also has collected a number of maps showing the main mineral deposits and occurrences, hydrocarbons, coal deposits and occurrences; nonmetallic minerals; metallic minerals and metallogenic zones; ferrous metals and fuel minerals; the nonferrous metals tin, tungsten, molybdenum; and bismuth; rare and precious metals; and hydrogeology. 
A selected annotated bibliography is presented in the appendix of this report. In addition, the Nathan/Berger team for this Delivery Order has compiled a comprehensive draft bibliography consolidating information on holdings at the three major libraries with those held at other locations. This bibliography is maintained at the Joint Venture's Arlington, Virginia, offices. 


\section{REFERENCES}

Afzali, H. "Les Resources d'Hydrocarbures, de Meteaux, et de Substances Utiles de l'Afghanistan," Chronique de la Recherche Miniere 49, 460 (1981).

Afzali, H. "Geological and Mining Bibliography of Afghanistan," Chronique de la Recherche Miniere 49, 465 (1982).

Amin, Hamidullah. A Geography of Afghanistan, 1976.

Assifi, A.T. "The Russian Rope," World Affairs 145, 3, Washington, D.C. (Winter 1982-1983): 252- 266.

Allan F. Agnew, Mineral Resources of Afghanistan, Congressional Research Service, Library of Congress, Washington, D.C., 1980.

Balcome-Rawding, R. and Cameron Porter, K. Afghanistan's Energy and Natural Resources (U.S. Department of Energy, Washington, D.C.: October 1989).

Cerkel, D. and Miller, R. Petroleum Law for Afghanistan (USGS, Kabul: 1958).

Fox, Ernest F. Travels in Afghanistan, New York, 1943.

Geology and Oil and Gas Potential of Northern Afghanistan. (Translated by Dorothy B. Vitiallano.) Translation for the U.S. Geological Survey, Translation File, USGS Library, Reston, Virginia, 1970.

Gregorian, V. The Emergence of Modern Afghanistan. Stanford CA: Stanford University Press, 1969, pp. 161-162.

"In Business Again," The Economist (September 14, 1990).

Kingston, John. The Undiscovered Oil and Gas of Afghanistan (Open-File Report 90-401, USGS Library, Reston, Virginia: 1990)

Nyrop and Seekins. Afghanistan:A Country Study. U.S. Government as Represented by the Secretary of the Army, 1986. 
Mennessier and Beun. Atlas des Cartes Geologiques de l'Afghanistan entre Gol-Bahar et l'Ab-e-Istada: Fosse de Kaboul et Prolonguements Meridionaux, 1985.

Ministry of Mines and Industries, Mineral Resources of Afghanistan, 2nd ed, (1977).

Ministry of Planning, Chapter on Industries and Mines for Eighth Supplement. A.I.D. Mission Library Report No. 490. Kabul, 1972. Translated by Gaussi.

Ministry of Planning, First Seven-Year Economic and Social Development Plan, (March 1976-March 1983). Kabul, 1976, pp. 1355-1361.

National Atlas for the Democratic Republic of Afghanistan. Organization for Surveying and Cartography, Warsaw, 1985.

"Resumption of Gas Export," Interview with Abdul Samad Saleh, Minister of Mines and Industry, The Kabul Times, (Kabul: May 15, 1991).

"Rich Spoils of Russia's War," London Telegraph Sunday Magazine (London: June 9, 1985).

Shroder and Assifi. "Afghan Mineral Resources and Soviet Exploitation," in Afghanistan: The Great Game Revisited, 1987, pp. 97-134.

Shroder. "Comparison of Tectonic and Metallogenic Provinces of Afghanistan to Pakistan, in Geological Bulletin 17 (1984): 87-100.

Shroder. "Physical Resources and the Development of Afghanistan," in Studies in Comparative International Development XVI (1981): 36-63.

Shroder. "Afghanistan Resources and Soviet Policy in Central and South Asia." In Afghanistan and the Soviet Union: Collision and Transformation, edited by Milan Hauder and Rovert L. Canfield. Boulder: Westview Press, 1989.

Simpson, John. "The Rare Stone that Buys Guns," World Monitor (September, 1990).

Smith, George I. Potash and Other Evaporite Resources of Afghanistan, USGS, Washington, D.C., 1973

Volin, M.G. Chromite Deposits in Logar Valley, Kabul Province, Afghanistan.

U.S. Department of Interior, Bureau of Mines, Washington, D.C., 1950.

Weisser, J.D. "Development Trends of the Non-Ferrous Metals Industry in the Former Soviet Union." The Post Soviet Metals Industry (Capital Metals \& Materials Forum sponsored by the U.S. Bureau of Mines and the U.S. Department of the Treasury, Washington, D.C.), January 23, 1992. 
Williams. Retrospective Review of US Assistance to Afghanistan: 1950-1979, 1957.

World Bank, Afghanistan:The Journey to Economic Development, 1978. 


\section{Appendix}

\section{ANNOTATED BIBLIOGRAPHY}

Copies of starred items are available at Nathan/Berger. Locations of unstarred items are indicated in the individual bibliographic reference.

\section{Government of Afghanistan Sources}

Ministry of Mines and Industries, Geology and Mineral Resources of Afghanistan, 1st ed. Kabul, 1973. Translated by G. Besulov and E.N. Kondrashkina. Held by Library of Congress.

Contains articles relating to four maps published by the Department of Geological Survey in the previous year (1972). Discusses the main features of the tectonics of Afghanistan, defines the main cycles of igneous activity and the associated mineralization, provides a general discussion of the mineral resources of Afghanistan, and provides some information on the petroleum and gas prospects in the Sangcharak Basin. This publication is replete with mistranslations and opaque English, and contains limited information, especially on the most important mineral deposits. See discussion in Chapter 4 of this report.

*Ministry of Mines and Industries, Mineral Resources of Afghanistan, 2nd ed, (1977). Held by Library of Congress and the Library of the University of Nebraska at Omaha.

This publication continues to be the best single source on Afghanistan's mineral resources. It represents an abridged version of previous work carried out for the Ministry including data on the geological surveys and mineralogical investigations carried out since 1963 by Soviet and Afghan geological teams Emphasizes the future economic potential of Afghanistan. It begins with a discussion of the main geologic features of Afghanistan, including stratigraphy, igneous rocks, and tectonics. The metallogenic features of the country are then discussed. With this as a framework, more than 1,400 specific mineral resource locations are described and classified into three categories: (1) deposits, (2) 
occurrences, and (3) showings. In addition, more than 300 broadly defined mechanical mineralogical haloes are discussed, because they suggest potential occurrences of specific minerals. An important concluding section deals with groundwater resources, defining the aquifers and describing specific localities-which include 86 freshwater wells and springs, mainly in the desert. Excellent maps are included in the report "Graph Annexes." Contains extensive list of references. See discussion in Chapter 4 of this report.

*Ministry of Planning, Chapter on Industries and Mines for Eighth Supplement. A.I.D. Mission Library Report No. 490. Kabul, 1972. Translated by Gaussi.

Written during the process of creating the Fourth Five-Year Plan (March 1972-March 1977). The translation of the Industry and Mines chapter contains a relatively detailed account of oil and gas exploratory work, the status of the chemical fertilizer factory then under construction, locations of mines and ore deposits, energy supply, and food and light industries. However, it omits any discussion of the large Ainak copper deposits. See discussion in Chapter 4 of this report.

*Ministry of Planning, First Seven-Year Economic and Social Development Plan, (March 1976-March 1983). Kabul, 1976, pp. 1355-1361.

Sets forth general policy framework emphasizing the development of minerals extraction and heavy industries through government initiative. Specific projects included iron smelting, copper smelting, petroleum refining, and a new fertilizer factory. See discussion in Chapter 2 of this report.

National Atlas for the Democratic Republic of Afghanistan. Organization for Surveying and Cartography, Warsaw, 1985. Held by the Library of Congress.

The Atlas contains some 51 maps including geology, tectonics, geomorphology, mineral resources, and hydrography. All of the maps are on the scale of 1:6,000,000. Pertinent maps of Afghanistan include a geological map; a geomorphological map; a hydrogeological map; a map of mineral deposits and occurrences of ferrous metals and fuel minerals; a map of mineral deposits and occurrences of nonferrous metals; a map of mineral deposits and occurrences of nonmetallic minerals; a map of mineral deposits and occurrences of rare and precious metals; a map of mineral deposits and occurrences of tin, tungsten, molybdenum and bismuth; a map of mines; and a tectonic map. See discussion in Chapter 4 of this report. 


\section{Eastern Bloc Sources}

"F. U. Akhmedzyanov, et al. "Angot: The First Oil Field of Afghanistan," in Geologiia Nefti i Gaza 12, Moscow (1972): 66-70. Summary by Paul Balasky of Nathan/Berger Team.

The Angot oil field is located in the Saripul region of Jowjan Province. In 1967, exploratory drilling into early Cretaceous rocks resulted in the first flowing well in Afghanistan. The daily production rate was 65 MT on a $5 \mathrm{~mm}$ choke. Seven additional exploratory wells were drilled in 1968-1970. These wells are also of commercial value and produces 29$340 \mathrm{~m}^{3}$ of oil per day. The oil belongs to a class of resinous, slightly sulfurous crudes with low paraffinicity.

*V.Y. Alkjazov, Z.M. Atakishiev, and N.A. Azimi, "Geology and Minerals of Early Quaternary Carbonatite Volcano of Khan-i-Shin (South Afghanistan)," Soviet Geology 4, Moscow (1977): 131-136. Summary by Paul Balasky of Nathan/Berger Team.

The carbonatite rock of the Khan-i-Shin Volcano contain promising amounts of rare earths and radioactive elements. Near-economical amounts of phosphorus, strontium, and iron also were discovered. Rare earths contain lead, niobium, and thorium. There is a possibility of finding additional carbonatite bodies associated with Khan-i-Shin.

*B.N. Androsov, V.P. Kolchanov, and V.V. Kulakov, Coal Bearing Deposits from the Northern Foothills of the Hindu Kush. Nawka, Moscow, 1977, pp. 1-133. Summary by Paul Balasky of Nathan/Berger Team.

The Dara-i-Suf region in northern Afghanistan is by far the most promising region further exploration. Its coal is of high quality, both as a fuel and an additive. The Saripul region requires further exploration. The coal reserves of the Pol-e-Komri region are limited. However, due to an acute shortage of fuel in this region, the commercial value of the Karakar-Dudkash field should be explored further.

"A. A. Borisov, "Subsurface Structure of the Murgab Buried Projection," in Geologiia Nefti i Gaza 3, Moscow (1961): 597-602.

This area in southeast Turkomenia lies between the International Boundary (the line between Tezden and Chardzou) and the Amu Darya River. The geology of the Murgab region indicates that this region should be a prime objective for oil and gas exploration. This assessment is strengthened by a gas well brought into production. 
V. I. Bratash, "Oil and Gas Potential," in Geology and Oil and Gas Potential of Northern Afghanistan, All-Union Scientific Research Institute of Geological Exploration, Ministry of Geology of the USSR (Nedra Press, Moscow: 1975). Translated for the U.S. Geological Survey by Dorothy B. Vitaliano, Translation File, USGS, Reston, Virginia (1985).

Technical discussion of oil and gas potentials in Northern Afghanistan.

*E. Karpeta, M. Dvorak, F. Novak (Mining Projects Institute, Czechoslovakia), "Unusual Project for Opening, Preparation, and Extraction of Karkar Dudkas Coal Deposit in Afghanistan," in Coal 31 (1983): 298-308. Translation by Matina Policarova for Nathan/Berger Team).

A long tradition of Czechoslovakian aid to Afghanistan's coal industry includes planning, technical assistance, and provision of equipment. In 1981-1982, the Mining Projects Institute in Ostrava undertook a study of the reconstruction and expansion of the mining of the Karkar-Dudkas deposit from $110,000 \mathrm{MT}$ per annum to $180,000 \mathrm{MT}$ per annum at a minimum. The deposit is the best in the Pul-e-Komri coal area in northern Afghanistan. Plans were developed for the period 1982-1985 and 1985-1990. The technical assistance team proposed an approach that would reach an optimal capacity of $180,000 \mathrm{MT}$ per annum in the first period and 230,000 MT were annum in the second period.

*A. Y. Kotchetkov, "The Character of Metallogenic Processes in Central and Western Afghanistan," in IsvestiiaVysshikh Uchenikh Zavedenii Geologiya i Razvedka 4, Ministry of Higher Education of the USSR, Moscow, 1976, pp. 7583. Summary by Paul Balasky of Nathan/Berger Team.

Central Afghanistan is characterized by deposits of polymetals and iron. Tin, mercury, and copper are predominant in the Farahrud region. The Arghandab region is characterized by a complex association of lead, copper, tungsten, fluorite, zinc, and gold.

*I.N. Rossovskiy, V.M. Chmyrev, and A.S. Salakh, "New Fields and Belts of Rare Metal Pegmatites in the Hindu Kush (Eastern Afghanistan)," in International Geology Review 18: 11, Washington, D.C. (1976): 1339-1342. Translation from Geologiya Rudnydnykh Mestorozhdeniy 17: 5, USSR (1975): 102-106.

The authors are with the Krasnoyarsk Division of the Siberian Scientific Research Institute of Geology, Geophysics, and Mineral Raw Materials. The rare-metal pegmatites in the territory of Nuristan and Badakhshan are spatially and genetically associated with the granites of the Lahgman complex, which form massifs markedly elongated in a northeasterly direction in accordance with the strike of the principal structures of the region. The recognized fields contain some of the 
largest concentrations of lithium in the world and apparently the largest accumulation of beryl and pollucite in Central Asia.

"L. N. Rossovskiy, V.M. Chmyrev, C.K. Yeremenko, and A.S. Salakh, "Lithium Deposits of Afghanistan," in IsvestiiaVysshikh Uchenikh Zavedenii Geologiya i Razvedka 7, Ministry of Higher Education of the USSR, Moscow, 1977, pp. 8693. Summary by Paul Balasky of Nathan/Berger Team.

The largest deposits of lithium in Afghanistan are located within the Parun ore district, $110 \mathrm{~km}$ to the northeast of Jalalabad. Deposits are estimated at 2.32 million MT. Only Canada has more lithium than Afghanistan. In addition to lithium, there are promising deposits of tantalum within the Parun district.

"M. Vajlupek, "Natural Resources of Afghanistan," in Geologicky Pruzcum: 22: 1, Czechoslovakia (1980): 16-18. Translation by Matina Policarova for Nathan/ Berger Team).

This general review of Afghanistan's mineral resources contains quantitative estimates of reserves of natural gas, oil, coal, and several ores and other minerals. Czechoslovakia's long-term involvement in assistance to Afghanistan is noted, including construction of the cement plant at Dzebel us Siraja and Ghori, coal mining at Karkar and Isput, and oil investigations near Herat.

\section{U.S. Government Sources}

*Allan F. Agnew, Mineral Resources of Afghanistan, Congressional Research Service, Library of Congress, Washington, D.C., 1980.

Reviews available literature on Afghanistan's mineral resources. Concludes that Afghanistan has high mineral potential because of its metallogenic setting and that sufficient data exists to verify the potential.

"Russell Balcome-Rawding and Kathryn Cameron Porter, Afghanistan's Energy and Natural Resources (U.S. Department of Energy, Washington, D.C.: October 1989).

Provides a natural resource perspective for planning reconstruction and economic development efforts in Afghanistan. Surveys opportunities for using mineral and energy resources to earn foreign exchange and lead economic growth. Discusses Afghanistan's mineral wealth as a reason for the Soviet invasion. See discussion in Chapter 2 of this report.

*David Cerkel and Ralph M. Miller, Petroleum Law for Afghanistan (USGS, Kabul: 1958). 
Includes chapters on reconnaissance permits, exploration permits, exploitation concessions, royalties and taxes, and rights and obligations of holders of petroleum rights.

James W. Clarke, Petroleum Geology of the Amu-Dar'ya Gas Oil Province of Soviet Central Asia (Open File Report 88-272), USGS Library, Reston, Virginia: 1988.

The Amu-Dar'ya gas oil province extends of an area of $360,000 \mathrm{~km} 2$ in central and eastern Turkomenia and western Uzbekistan. The province extends southeastward into Afghanistan covering an additional area of about $45,000 \mathrm{~km}^{2}$. The province in gas-prone. In most areas, no oil is present.

"Pete J. Dunn (Department of Mineral Sciences, Smithsonian Institution, Washington, D.C.), "Gem Spodumene and Achroite Tourmaline from Afghanistan," Journal of Gemmology and Proceedings of the Gemmological Association of Great Britain 14, 4. London, (1974): 170-174.

Provides favorable assessment and technical description of gem quality spodumene and tourmaline discovered in pegmatites (then) recently discovered in Afghanistan.

John Kingston, The Undiscovered Oil and Gas of Afghanistan (Open-File Report 90-401, USGS Library, Reston, Virginia: 1990)

Contains estimates of discovered and undiscovered reserves of natural gas and petroleum in Afghanistan. Available as USGS Library only.

Nyrop and Seekins, Afghanistan: A Country Study. U.S. Government as Represented by the Secretary of the Army, 1986.

*George I. Smith, Potash and Other Evaporite Resources of Afghanistan, USGS, Washington, D.C., 1973

Evaluation of seven sites of evaporitic resources. Three sites were found to contain magnesium minerals but to lack nearby markets. Two sites had marginal quantities of potassium (potash), but only one had an adjacent area suitable for solar evaporation ponds. Test drilling was recommended at two sites, one containing magnesium and one containing potassium.

* M.G. Volin, Chromite Deposits in Logar Valley, Kabul Province, Afghanistan. U.S. Department of Interior, Bureau of Mines, Washington, D.C., 1950.

Records the findings of 1949 investigations of 11 chromite occurrences in the Logar valley in Northeast Afghanistan undertaken for the Ministry of Mines. The work was carried out under the supervision of two 
Americans temporarily assigned from the U.S. Bureau of Mines. A U.S. mining consultant to the Ministry of Mines organized the investigations. Three of the deposits were mapped by an employee of the U.S. Geological Survey. Morrison Knudsen Afghanistan, Inc. did the drilling under contract.

\section{Other Sources}

"H. Afzali, "Les Resources d'Hydrocarbures, de Meteaux, et de Substances Utiles de l'Afghanistan," Chronique de la Recherche Miniere 49, 460 (1981). Contains a broad overview of Afghanistan's hydrocarbon, metal, and industrial mineral resources, written by the former Director of the Afghan Geological Survey.

"H. Afzali, "Geological and Mining Bibliography of Afghanistan," Chronique de la Recherche Miniere 49, 465 (1982).

Excellent geological and mining bibliography. Divided into sections on general geology, distributions, and characteristics of minerals resources. Provides descriptions of ore deposits and metallogeny.

"A.T. Assifi, "The Russian Rope," World Affairs 145, 3, Washington, D.C. (Winter 1982-1983): 252- 266.

Soviet plans, agreements, and contracts concerned with exploitation of natural gas and other minerals in Afghanistan reflected a policy of devious and clandestine rapacity. In the 1970s, the Daoud government's plans to construct an internal pipeline southward from the natural gas fields in the north were tied in with the exploitation of Ainak copper and Hajigak iron ore. The Government was ultimately prepared to accept funding from a consortium of private companies for mineralsrelated investment. Written by former Minișter of Mines and Industries.

*Vartan Gregorian, The Emergence of Modern Afghanistan. Stanford, Calif. Stanford University Press, 1969.

Describes policies, attititudes, and activities concerning railroad construction, natural resource development, and foreign investment during the period $1880-1946$.

"Erwin Grotzbach, "The Problem of Natural Resources and Their Effective Use in Afghanistan," in Geodynamik 2, Damstadt (1982): 141-168. Translated by Rolph Sloss.

Provides an overview of water and energy problems. 
"Homilius, J. "Geophysical Investigations in East Afghanistan," in Geophysical Prospecting 17, 9, The Hague (1969): 468-487.

Investigations carried out under West German Technical Assistance in 1965-1967 related to groundwater, mineral, and other assistance being provided by the German Geological Mission to the Afghan Geological Survey.

Guy Mennessier and Noel Beun, Atlas des Cartes Geologiques de l'Afghanistan entre Gol-Bahar et l'Ab-e-Istada:Fosse de Kaboul et Prolonguements Meridionaux. Departement de Geologie de l'Universite de Picardie, Amiens, 1985. Held at the USGS Library in Reston, Virginia. Call Number G(540) qT697d t.2.

Contains five geologic maps of areas between Gol-Bahar and Ab-eIstada.

*Alfred Shreiber, Dietrich Weippert, Hans-Peter Wittekindt and Reinhard Wolfart. "Geology and Petroleum Potentials of Central and South Afghanistan," in The American Association of Petroleum Geologists Bulletin 56, 8. Tulsa (August 1972): 1494-1515.

The authors were members of the 1965-1967 Geological Mission to Afghanistan of the Federal Republic of Germany. The best prospects for discovery of economically exploitable hydrocarbons appear to exist in the Katawaz fault block of southeastern Afghanistan. A syndepositional high seems to exist in the marine Mesozoic formations in the vicinity of Ghomel. No prospects or, at best, poor prospects exist elsewhere in central and south Afghanistan. Seismic reconnaissance surveys would provide more precise data pertinent to the existence of favorable structures.

*John F. Shroder, Jr. and A. Tawab Assifi, "Afghan Mineral Resources and Soviet Exploitation," in Afghanistan:The Great Game Revisited, edited by Rosanne Klass. Freedom House, 1987, pp. 97-134.

Views 1979 invasion of Afghanistan as consistent with a Soviet aim of achieving control of key resources as well as other geopolitical objectives. Severely criticizes Soviet handling of gas pricing and related practices. Reviews Afghanistan's exploration history through the Soviet occupation. Identifies major mineral deposits.

\section{Newspapers and Magazines}

"Colored Stone Tucson Show Guide," Coloured Stone Magazine, 1992. 
Guide for a gemstone industry show held in Tucson, Arizona from February 3 through February 16, 1992. The guide contains listings for Afghan Basar Gems, Afghan Gems and Minerals, Afghan Lapis Gems and Minerals, Afghan Mountain Gems, Geovision, and Golden Horde, firms that deal in materials from Afghanistan. These organizations offer lapis lazuli, kunzite, tourmaline, emerald, ruby, aquamarine, cameos, carvings, jewelry, and cutting materials for sale to the trade.

"In Business Again," in The Economist London: September 14, 1990), p. 40.

Khenj in Northeastern Afghanistan is prospering as local people collaborate in traditional forms of emerald mining.

"L. Natawaz, "Sufficient Amount of Coal Available for Distribution in Winter," The Kabul Times (Kabul: September 15, 1991).

Reports plans for coal distribution in Kabul by the Director of the coal briquette factory. The coal is being brought to Kabul from Baghlan Province.

"James Rupert, "Soviet's Underground War," Washington Post (Washington, D.C.: October 20, 1986).

Reports resistance efforts to prevent exploitation of copper at Ainak together with general assessment of Soviet efforts to exploit minerals during the war.

"John Simpson, "The Rare Stone that Buys Guns," World Monitor (September, 1990), p. 10.

Discusses Afghanistan's wartime trade in lapis lazuli, which comes from a single mountain in the northeastern section of the country.

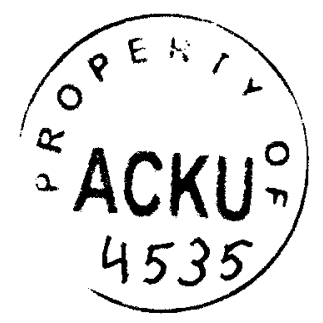


note:

The original material azu_acku_pamphlet_qe290_m56_1992: page 008 blank. The original material azu_acku_pamphlet_qe290_m56_1992: page 024 blank. The original material azu_acku_pamphlet_qe290_m56_1992: page 084 blank. 